ECONOMICS

\title{
INVESTMENT AND SHARE PRICES: FUNDAMENTAL VERSUS SPECULATIVE COMPONENTS
}

by

Christopher B Branston

and

Nicolaas Groenewold

The University of Western Australia 


\section{Investment and Share Prices: Fundamental versus Speculative Components}

by

Christopher B Branston

and

Nicolaas Groenewold*

Department of Economics, University of Western Australia,

Crawley, WA 6009

Australia

*Corresponding author; phone +61 89380 3345, fax +61 89380 1016, e-mail nic.groenewold@uwa.edu.au. We are grateful to the Department of Economics for research support in the form of a Departmental Research Grant and to participants at a seminar at Curtin University for useful feedback. 


\title{
Investment and Share Prices: Fundamental versus Speculative Components
}

\begin{abstract}
This paper uses quarterly US data from 1953(6) to 2000(6) to investigate the effects of share-price changes on investment. We focus on the distinction between speculative and fundamental components of share-price movements and we contribute to the literature by evaluating four alternative methods of decomposing share-price movements into these two components. The four methods are: (1)a decomposition based on regressing share-returns on a set of variables designed to capture fundamentals; (2)the use of the price-earnings ratio; (3)the use of the dividend yield and (4)a structural VAR model based on the dividend-discount equation. We find that, no matter what the method of decomposition is, shocks to both fundamental and speculative components have positive effects on investment and that, in contrast to the earlier literature, the effect of the speculative shock is at least as large as that of a shock to fundamentals.
\end{abstract}

JEL Codes: E22, E44

Keywords: investment, stock prices, fundamentals 


\section{Introduction}

Both macroeconomists and finance specialists are giving increasing attention to the relationship between the stock market and the rest of the economy. There can be little doubt about the growing importance of the stock market from the point of view of the aggregate economy. In the US the ratio of stock-market capitalisation to GDP has approximately tripled in the last 25 years - from less than $30 \%$ in the mid1970 s to over $80 \%$ in the late 1990 s. There has, for example, been considerable recent discussion of whether central banks ought to respond to asset prices as well as inflation in setting their monetary policy. ${ }^{1}$

Not only has the stock market increased relative to the real economy, but it appears that the inter-relationship between them has strengthened. It has always been recognised that the stock market reflects to some extent the goings on in the rest of the economy but recently there has been widespread recognition that the influence may also be in the opposite direction - dramatic events in the stock market are likely to have an impact upon the real economy. There were concerns at the end of the 1990s of the potential adverse consequences for economic activity of a possible dramatic fall in stock prices as they unwound from their historically high levels.

The relationship between the stock market and the economy as a whole has not been absent from the literature in economics and finance. There are various ways in which the stock market and the macroeconomy have been related in the literature. Consider first the effect of macroeconomic events on stock prices. One approach has been from an asset-pricing perspective in which the Arbitrage Pricing Theory (APT) was used as a framework to address the question of whether risk associated with particular macro variables is reflected in expected asset returns; the original work in this area is by Chen, Roll and Ross (1986) who applied the model to the US. A closely-related analysis is that of the consumption-CAPM which concentrates on a single macro influence, the growth of aggregate consumption; see, e.g., Breeden (1979) and Grossman and Shiller (1981).

The direction of influence underlying the asset-pricing literature is the traditional one - from the economy to the stock market. A similar focus is found in the literature which explores the response of aggregate stock prices to the (expected)

\footnotetext{
${ }^{1}$ See for example, recent pronouncements by Alan Greenspan of the US Fed and UK Monetary Policy Committee of the Bank of England.
} 
inflation rate; early work carried out in this area is by Bodie (1976), Fama and Schwert (1977), Jaffe and Mandelker (1976) and Nelson (1976) whereas more recent applications include those by Balduzzi (1995), Graham (1996) and Siklos and Kwok (1999). Similar studies assess the response of the stock market (often, but not always, at an aggregate level) to other macro variables such as those which capture monetary and fiscal policy shocks; e.g. Pearce and Roley (1985), Jain (1988), Aggarwal and Schirm (1992), Singh (1993) and Gilchrist and Leahy (2002).

An alternative to this direction of influence from the economy to the stock market is to analyse the effects of stock prices on the macroeconomy or selected macroeconomic variables. One possibility is the effect of changing stock prices on consumption - asset prices affect wealth which in turn affects consumption according to most standard theories of consumption such as the Life-Cycle Hypothesis and the Permanent Income Hypothesis. Empirical work by Poterba and Samwick (1995) and Starr-McCluer (2002) suggests that this relationship is relatively weak.

Another relationship of this nature which has received considerable attention is that between stock prices and investment and this is the subject of the present paper. There has been considerable debate about whether we should expect stock prices to provide useful information for managers in their formulation of investment plans or whether the stock market is just a "side-show" in the words of Morck et al. (1990). In the latter view stock prices simply reflect (imperfectly) the same expectations that managers form as the basis for investment planning and therefore do not contain information that is not captured by other more basic determinants of investment. On the other hand, various theories of investment such as Tobin's (1969) Q-theory of investment and the neoclassical theory of investment associated with Jorgenson (1971) clearly have room for the influence of stock prices through their effect on the market value of capital in the first case and through their effect on the cost of capital in the second.

Empirical work on this relationship ranges from simple single-equation models to more sophisticated multi-equation models constrained by overtly theorybased restrictions. The evidence is mixed and, despite two decades of research, the issue of whether and to what extent share price fluctuations affect investment is by no means settled.

Early work simply regressed investment on stock prices (in levels or first differences) and tested the significance of the stock-price regressors. In view of the 
theory of investment this equation is mis-specified, however, since there are other determinants missing and it is likely that the stock price variables are picking up the effects of the missing determinants. To overcome this and test whether stock prices have explanatory power in the presence of traditional investment determinants, a common approach is to perform the following regression:

$$
\Delta \ln I_{t}=\alpha+\sum \beta_{i} \Delta \ln D_{t-i}+\sum \delta_{i} \Delta \ln S P_{t-i}+\varepsilon_{t}
$$

where

$\Delta \ln I_{\mathrm{t}}=$ growth in business fixed investment

$\Delta \ln D_{\mathrm{t}}=$ growth in the determinants of investment other than stock returns

$\Delta \ln S P_{\mathrm{t}}=$ stock returns.

One can then test the hypothesis that $\delta_{\mathrm{i}}=0$ for all $\mathrm{i}$. If the stock price variable is significant, a conclusion can be made that it affects investment spending independently of the more traditional determinants.

The evidence from the application of this procedure is mixed. Early papers by Fischer and Merton (1984), and Doan et al. (1983) report that the share market has predictive power for US data, even when allowance is made for other determinants of investment. Fischer and Merton (1984) include finance variables and lagged real GDP growth in the equation as additional factors causing investment and conclude that the share market is indeed a prominent cause of investment. Barro (1990) also finds that even with the inclusion of cash flow variables, such as contemporaneous and lagged values of after tax corporate profit, the share market still retains significant predictive power. Mullins and Wadhwani (1989) conduct a multi-country comparative study, and find cross-country differences in the effect of share prices on investment. While the focus of their paper is on how the level of managerial autonomy affects the relationship between the share market and business investment spending, their results throw interesting light on the question of the effect of share prices on investment. They estimate a Neoclassical or Flexible Accelerator Model, modified to incorporate the probability of bankruptcy. The results concur with the authors' expectations; the stock market has a much greater influence on the investment process in the US and the UK than in Japan and Germany which is attributed to the lower degree of management autonomy in the US and UK, illustrated by a more active takeover mechanism, relatively lower gearing ratios, and a less important role for employees in corporate decision making. 
More recent papers have achieved different results, primarily finding that share prices play only a minor role in determining investment. The most comprehensive of these studies is by Morck et al. (1990), who first develop four theories of the relationship between the share market and investment, and then set about testing them with US data.

The first two of these theories are the passive informant and active informant hypotheses, the third is called the financing hypothesis (which is similar to the Q theory), and the fourth theory is the stock market pressure hypothesis. The passive informant hypothesis states that share prices reflect imperfectly what investment managers already know so that the correlation between share prices and investment is simply a coincidence. In this case bubbles in share prices will not influence investment since, by definition, they do not reflect forecasts of fundamentals.

The active informant hypothesis, on the other hand, states that share prices convey information that investment managers act on. Unless managers are able to distinguish between price movements which reflect fundamental from those which result from non-fundamentals (henceforth, speculative factors), the active informant hypothesis implies that share prices will affect investment even when fundamentals are controlled for.

This is also the case under the third theory, the financing hypothesis. This is based on the fact that the higher are share prices the cheaper is equity finance so that as share prices rise, previously marginal investment projects are undertaken. Blanchard et al. point out, however, that managers may simply buy financial assets or retire debt when share prices are high rather than undertake additional investment projects.

The fourth theory is that investment managers react to share-market sentiment per se - if shareholders disapprove of managers' actions, they sell shares and share prices fall. Managers' jobs being at stake, they disinvest even though they may believe that the share market is misinformed. This generates a positive relationship between share prices and investment of the type commonly observed.

Morck et al. use firm-level and aggregate data in their study, regressing investment on variables thought to be fundamentals: cash flows, sales growth, private consumption, and changes in stock prices. The authors conclude that share prices add little explanatory power to the investment equation once other influences are taken 
into account; while the stock market may not be a 'sideshow', it is by no means a central determinant of investment.

One response to the ambiguous results obtained from the regression of investment on share returns and other variables is to attempt to distinguish directly between fundamental and speculative components of returns and ask whether these components have different effects on investment. The most straightforward approach to this question is a two-stage approach which first regresses share prices or returns on a set of variables which determine fundamentals and then uses the predicted values and residuals to measure fundamental and speculative components of share prices which are used as regressors in the investment equation. Blanchard et al. (1993), Galeotti and Schiantarelli (1994) and Anderson and Subbaraman (1996) are examples of this approach. Again, the evidence is conflicting. Blanchard et al. interpret their results as "pointing strongly, but not overwhelmingly, to a more important role for fundamentals" in the explanation of investment, thus confirming the results by Morck et al. (1990). Similarly, Galeotti and Schiantarelli find that both components influence investment although they conclude that fundamentals have a larger effect. On the other hand, Anderson and Subbaraman find that neither component is an important influence on investment.

An alternative approach has been implemented by and Chirinko and Schaller (1996). They estimate an Euler equation and the Q-equation simultaneously and interpret one test of orthogonality conditions as a tests of the presence of a speculative component in share prices and another as a test of the effect of the speculative component on investment. Using annual US data for 1911-1987, they find evidence of bubbles in share prices but no evidence that these bubbles affect investment with fundamentals being the only share-return component that influences investment. In this sense their evidence is consistent with earlier US evidence reported by Blanchard et al. (1993).

Thus, regressions of investment on share prices or returns have not provided a definite answer to the question of whether investment behaviour is influenced by events in the share market although the preponderance of the evidence, at least for the US, is that fundamentals are more important than speculative components. A weakness of this line of research is that the two share-return components are not directly observable so that auxiliary assumptions need to be made in order to identify them. Since these assumptions necessary to identify the two components are not 
uncontroversial - witness the continuing debate over whether the stock market is over-valued - it is necessary to explore alternative assumptions to investigate the sensitivity of the results to the particular way in which the components are identified. Our paper contributes to the literature by doing this. We use quarterly US data from June 1953 to June 2000 for the following analysis. We begin by re-estimating the standard regression equations relating the change in investment to the change in share prices as well as other determinants commonly used. We simulate the effects of a share-return shock on investment but recognise that most if not all the variables in the investment equation will be endogenous and therefore embed the simulation in a VAR model to capture the lagged feedback. We use this simulation as a benchmark for further simulations. We then extend the analysis by distinguishing between fundamental and speculative components of share prices in various ways. We begin with the common regression approach whereby we regress share returns on a number of variables designed to capture the fundamental forces and then use the generated values from the regression as fundamentals and the residuals as speculative components. We then use two approaches from finance based on the price-earnings ratio and the dividend yield since these are commonly used in practical finance to assess the value of share prices relative to their long-term (fundamental) values. We finally explore the implications of a decomposition based on the dividend-discount equation using a structural VAR model based on the work of Campbell and Shiller $(1987,1988)$. We simulate the effects on investment of a shock to fundamental and speculative components separately for each of these approaches and compare them to our benchmark simulations. We find that in all cases, both speculative and fundamental shocks have positive effects on investment and that, in contrast to the existing literature, on the whole the speculative shocks have a larger effect than shocks to the fundamental component.

\section{Data}

The US data in this paper is quarterly for the period June 1953 to June 2000. The share price data is the same series used in the Black et al. (2001) study, namely the S\&P 500 composite index adjusted for inflation. This was initially obtained from the database of Ibbotson Associates. Investment is defined as real private nonresidential fixed investment, collected from the Federal Reserve Bank of St. Louis database, FRED ${ }^{\circledR}$. This conforms with the measure most commonly adopted in the 
literature, and is logical because broader definitions of investment (that include for example residential investment and consumer durables) don't relate as directly to stock prices. $^{2}$

Figure 1 pictures the data for share prices and investment for the period 1947 to 2000. There appears to be a strong relationship between them with share prices often exhibiting a leading property, although the relationship may simply reflect a common trend. To eliminate the common trend, Figure 2 graphs the variables in log first differences. This gives the useful interpretation of returns to shares and percentage growth in investment. We can see that the positive relationship is still observed under this specification, and also that share returns are considerably more volatile than investment.

[Figure 1 about here]

[Figure 2 about here]

Consider now the determinants other than share prices. The selection of the other determinants of investment is based on the analysis of investment models and existing empirical work briefly mentioned in the previous section. The variables used are real output, real corporate profits and a measure of the debt component of the cost of capital suggested by the Jorgenson model. Data for these variables was obtained from Datastream. The output variable is constant dollar GDP and real profits are measured after tax. The real 10 year treasury yield (adjusted by the CPI) proxies for the debt component of the cost of capital. The long-term yield is chosen because it is believed investment decisions will primarily be made with this horizon in mind.

Table 1 provides summary statistics of the main variables of interest, with share prices, output, profit and the CPI expressed in log first differences (percentage growth).

\section{[Table 1 about here]}

All the variables show significant deviations from normality and all but the real return to shares and the change in real profits show strong evidence of autocorrelation.

Before specifying the form of the variables to appear in the models, we test for stationarity using the Augmented Dickey-Fuller (ADF) test. Panel A of Table 2 shows that all variables with the exception of the real long-term treasury yield appear to be nonstationary in log levels. In panel B, we can see that all variables become stationary

\footnotetext{
${ }^{2}$ Barro (1990, p. 116) discusses this point.
} 
in log first difference form, leading to the conclusion that the 10 year yield is $\mathrm{I}(0)$, while investment, share prices, profit and GDP are I(1).

\section{[Table 2 about here]}

Given that all but one of the variables are I(1), we next test for cointegration using the procedure due to Johansen. ${ }^{3}$ We use the AIC and SBC criteria to establish the order of the VAR for the Johansen test and find that an order of 3 is adequate. The Johansen cointegration test results are presented below in Table 3.

\section{[Table 3 about here]}

It is clear that the variables are not cointegrated and that this conclusion is not dependent on whether there is a trend in the model or not and which of the two tests is used. We therefore specify the model such that all variables appear in first difference form with the exception of the treasury yield which we include in level form.

\section{Results}

In this section we present our estimation and simulation results. We begin with the case where no distinction is made between speculative and fundamental components of share prices. This allows us to present the results for the case most commonly reported in the literature using our data set and compare our results to those presented elsewhere. We then go on to consider the implications for the results of dividing share prices into speculative and fundamental components to investigate whether these have different effects on investment. Since the two share-price components can not be directly observed, we must generate them on the basis of a model of share-price fundamentals and given that such a model is far from uncontroversial, we experiment with four alternative models to assess whether our results are sensitive to the method of decomposition.

Before proceeding to the presentation of the estimation and simulation results, we briefly discuss the importance of lags in the investment function. Investment theory often assumes that levels of capital can adjust instantaneously to a change in the business environment. However, in reality investment is subject to substantial lags. Investment plans tend to be made between one quarter and a year in advance of the actual investment spending (Lamont, 2000, p. 2720). Therefore, we would expect changes in investment determinants to be followed by changes in investment during

\footnotetext{
${ }^{3}$ See Johansen (1988) and Johansen and Juselius (1990).
} 
the next few quarters but not contemporaneously. Chirinko (1993, p. 1887) also notes that if all restrictions implied by optimal behaviour were considered simultaneously in the explicit models, the paths of investment would be sluggish and depend on lagged variables. Barro (1990, p. 115) recognised this slow adjustment as 'time to build technology', but one would also expect lags in raising funds, placing orders, deliveries, and possibly even making the decision to invest.

To focus on the relationship between share prices and investment, consider the response from an increase in share prices. Management will first make the decision to invest more, but the process of issuing equity to fund the new project may take a months. Similarly, a decrease in share prices will not lead to an immediate drop in investment because the funds are already committed to certain projects. The reaction of investment to other variables is also likely to be over a period of time. A positive change in output for instance may signal an increase in future demand, leading managers to change investment plans to increase spending in the next period.

On the basis of this brief discussion, we specify the investment function solely in terms of lagged determinants. Apart from according with intuition and precedent, it has two practical econometric advantages. First, we avoid the endogeneity problem at the econometric level and use OLS throughout. Given the nature of the investment process, we exclude the possibility that there is contemporaneous two-way feedback between investment and its determinants. Second, it implies that the single investment equation we report for various cases can be seen as a component of a more extensive VAR which we subsequently simulate. ${ }^{4}$

\section{$\underline{3.1 \text { Results using Total Share Prices }}$}

Consider first the simple equation relating the change in the log of investment to lags in the change in the log of the share-price index (the continuouslycompounded share return). It is given as equation (1) in Table 4.

\section{[Table 4 about here]}

Following the tests for the appropriate lag length preceding our cointegration tests, we estimate equations with three lags for all variables including the dependent variable. Regressions with possible autocorrelation and heteroscedasticity are reported with

\footnotetext{
${ }^{4}$ Limited experimentation with an equation with the traditional determinants of investment entered in current as well as lagged form shows that this alternative form does not affect our conclusion about the significant role of lagged share returns.
} 
Newey-West adjusted standard errors based on a truncation lag of 30 periods; by and large results are not sensitive to this lag choice.

As expected, all share price coefficients are positive and highly significant in equation (1) in Table 4 which supports the visual evidence in Figures 1 and 2 and results reported in earlier studies. As argued above, however, this may simply reflect share returns picking up the effects of omitted variables. We therefore estimate as equation (2) a traditional investment equation without share prices and then, in equation (3), combine the two sets of regressors. Each of the variables in equation (2) has at least one lag that is significant at the 5\% level. In addition, the coefficients with the highest t-ratios have theoretically correct signs with output and profits positively related to investment and increases in the treasury yield leading to falls in investment spending. The adjusted $\mathrm{R}^{2}$ of 0.39 is higher for this regression than the 0.35 reported in the initial regression including only share returns, suggesting that the traditional variables have greater explanatory power than lagged share returns alone.

When the two sets of variables are combined in equation (3) we are able to test whether returns to shares are still important in explaining investment when other investment determinants are taken into account. We can see that when all explanatory variables are included, the first lag of share prices is significant at the $5 \%$ level, and the second lag remains significant at the $1 \%$ level but the third which was previously significant is now insignificant. Moreover, the magnitude of each of the coefficients of the lagged share price terms is slightly smaller than in the previous case. Comparing the output coefficients with and without the presence of share prices in the equation, suggests some overlap between these two variables as determinants of investment. However, it is clearly not the case that share prices merely proxy for output and other fundamental factors - the Wald statistic for the test that all the lags of share prices are jointly zero has a prob value of $0.000 .^{5}$ The adjusted $\mathrm{R}^{2}$ value increases from 0.39 for equation (2) to 0.45 for equation (3), providing further indication that share prices have additional explanatory power for investment. Moreover, the explanatory power of the equations is comparable to that commonly reported in the literature. We conclude that these findings support the early literature

\footnotetext{
${ }^{5}$ We have also run an OLS regression with share prices lagged one period behind all other variables in an attempt to assess the conjecture that share prices may just provide information on expected future changes in investment determinants. The results are similar to those in Table 4, with the second lag of share prices remaining significant at the $1 \%$ level. In addition, the primary conclusions were found robust to alternative specifications of profits such as cash flow after tax, and profit/output ratios.
} 
of Fischer and Merton (1984) and Doan et al. (1983), who report a causal relationship between share returns and investment, even when other traditional explanatory variables are added to the investment equation.

We proceed from a consideration of the regression equation for investment to the question of the dynamic response of investment to a change in share prices. An analysis of the equations reported in Table 4 would neglect the lagged feedback through the other determinants. Thus a shock to share prices would affect investment according to equation (3) in Table 4 but it is likely that other variables such as output and profits would also be affected, either directly by the share-price shock or indirectly through the change in investment and these changes would, in turn, affect investment. We allow for this lagged feedback by embedding equation (3) of Table 4 in a VAR model comprising investment, share prices, output, profits and yield, all with three lags. We capture the dynamic effects of a share-price shock on investment by an impulse response function (IRF), using the generalised impulse response approach developed by Koop et al. (1996) and Pesaran and Shin (1998). This approach does not have the problem often observed with orthogonalised impulse responses, where results are sensitive to the ordering of variables in the VAR but instead computes responses that capture the historical relationships between the VAR errors and is independent of the ordering of the variables in the model. The effect is captured in Figure 3.

\section{[Figure 3 about here]}

Figure 3 illustrates the positive response of investment to a one standard error shock in share returns. This relationship can be explained by increases in share returns decreasing the cost of capital, or alternatively increasing the value of q, making investment more profitable. We can see that the peak of $0.8 \%$ is reached between the second and third quarter and most of the response is completed after around two years. This time profile is consistent with that reported in the literature and the adjustment lag falls within the range of one year suggested by Lamont (2000, p. 2720) for plans to take effect and four years proposed by Bosworth (1975, p 283) for full adjustment to take place.

We now turn to the question of the separate effects of fundamental and speculative components of share prices. 


\section{$\underline{3.2 \text { Results using a Decomposition of Share Prices }}$}

The results to this point provide strong support for the hypothesis that share prices play a role in determining investment, even in the presence of traditional determinants of investment. We next decompose share prices into their fundamental and speculative components. While this exercise may be interesting in its own right, we use the decomposition to test whether managers, in making investment decisions, react differently to share price changes they believe are warranted and those driven more by market sentiment than by the fundamental forces.

Recognising that there are many alternative possibilities for the decomposition, we use the four different methods. We start with the use of a regression equation which explains share prices in terms of variables commonly considered to drive fundamentals and use the predicted values from this equation for fundamentals and the residuals for the speculative component of share prices. We then go on to use two rules of thumb often used in popular finance literature to identify whether shares are overvalued, viz., the price-earnings ratio and the dividend yield. Finally, we use a model of share-price fundamentals based on the work of Campbell et al. (see Campbell and Shiller, 1987, 1988, Campbell and Ammer, 1993) and applied to US data by Black et al. (2001).

\subsubsection{Regression-Based Fundamentals}

For the OLS regression approach we derived an equation from a model which states that fundamental share prices are simply the present value of the future returns to capital which, in turn, are related to the rate of growth of output, the rate of growth of wages and the change in the discount rate using the assumption of a two-factor production function with Cobb-Douglas technology. We therefore estimate an equation of the form:

$$
\Delta \ln S P_{t}=\alpha+\sum_{i=1}^{3} \beta \Delta \ln Y_{t-i+1}+\sum_{i=1}^{3} \delta_{i} \Delta \ln W_{t-i+1}^{x}+\sum_{i=1}^{3} \phi_{i} \Delta \ln r_{t-i+1}
$$

where $\mathrm{Y}$ represents real output, $\mathrm{W}^{\mathrm{x}}$ is the wage gap measured by wages per hour multiplied by the number of total labour hours divided by Gross National Product and $\mathrm{r}$ is the 3 month T-bill which proxies for the required rate of return. All variables are in real terms and the data were collected from Datastream. The equation has modest explanatory power with an $\mathrm{R}^{2}$ of 0.17 which is comparable to other reported equations for the aggregate return to shares. The fundamental component of share prices is then 
computed as the predicted values from the estimated equation and the actual and fundamental share price series are displayed in Figure $4 .^{6}$

\section{[Figure 4 about here]}

We can see that under this decomposition, fundamental share prices have, as expected, been markedly smoother than actuals and they have been above actual share prices for the majority of the period, although this feature has no implications since it reflects the arbitrary starting point for the fundamentals.

We now proceed to the use of the computed components of share prices in the investment equation. ${ }^{7}$ The results are reported in the first set of columns of Table 5.

\section{[Table 5 about here]}

The results show that, surprisingly, investment is significantly related to speculative but not to fundamental share prices. The second lag of the speculative return series is significant at $1 \%$ and the third at $5 \%$ while all lags of the fundamentals are insignificant. These results are confirmed by the Wald tests for the exclusion of the fundamental and speculative terms respectively. They show that the fundamental terms are jointly insignificant but that the speculative terms are jointly significant. However, tests of equality of coefficients of the speculative and fundamental components (either individually or in sum) show that the hypothesis of equality cannot be rejected although this is no doubt largely the result of the large standard errors for the speculative coefficients. The coefficients of the speculative returns are all positive and are quite close in magnitude to those of total returns reported in Table 4 , even before other investment determinants were added to the equation. Thus, not only does the addition of traditional investment determinants have little effect on the importance of share prices for investment behaviour, a further decomposition of share prices into fundamental and speculative components shows that the speculative component captures effectively all of the influence of total returns with the fundamental component being completely insignificant. This result is quite contrary

\footnotetext{
${ }^{6}$ Note that the equation will allow us to generate only the change in fundamentals. To obtain a figure for the level of fundamentals pictured in Figure 4 we assumed that the actual and fundamentals components were equal at the beginning of the period. This arbitrary assumption will not affect our results below since it is only the change in share prices which appear in our investment equation.

${ }^{7}$ It is recognised that this procedure introduces a generated-regressor problem in sense of Pagan (1984); see also McAleer and McKenzie (1991) and Oxley and McAleer (1993). However, our models are more complicated than any of the cases for which Pagan gives rules for correcting the standard errors. We therefore report "OLS" standard errors but keep in mind that these may be misleading although experimentation with a simpler model for which the Pagan corrections are appropriate indicate that the corrections have only very minor effects on the standard errors.
} 
to previously-reported results but makes sense in term of Morck et al.'s hypotheses. It allows us to dismiss the passive informant hypothesis and is consistent particularly with the financing and market-sentiment hypotheses in which managers take account of share prices even if they know that they do not reflect fundamentals.

We consider also the dynamic reaction of investment to share returns which allows not only for the direct influence as captured in the estimated equations in Table 5 but also for the indirect feedbacks via the other determinants. As explained above, we achieve this by considering the investment equation as part of a 6-variable VAR and generating the generalised IRF for investment with respect to the speculative and fundamental components of share returns. The results are pictured in Figure 5.

[Figure 5 about here]

The impulse response function shows that both speculative and fundamental components have an effect on investment. The profile of the effect of the speculative shock is very similar to that of the shock to total returns pictured in Figure 3, thus confirming the conclusions we drew from the regression results. While the shock to the fundamental component also has a positive effect on investment, it is much slower to get going, peaks at about $50 \%$ of that of the other effect and is longer-lasting.

\subsubsection{Fundamentals Based on the Price-Earnings Ratio}

We now consider the second of our methods of decomposing share returns into fundamental and speculative components, viz., by using the price-earnings ratio.

The financial press, market analysts and many academics commonly discuss share valuation in terms of financial ratios and use measures such as the priceearnings $(\mathrm{P} / \mathrm{E})$ ratio, the dividend yield or dividend-price ratio $(\mathrm{D} / \mathrm{P})$ and the book-tomarket $(\mathrm{B} / \mathrm{M})$ ratio to determine whether shares are underpriced or overpriced. The $\mathrm{P} / \mathrm{E}$ ratio is perhaps the most commonly cited. The underlying assumption of such analysis is that there is some long-term value to which the ratio returns. This can be based on the Gordon model of share valuation and has also been the subject of empirical work. Thus, Campbell and Shiller $(1998,2001)$ use regression analysis to show that periods of high $\mathrm{P} / \mathrm{E}$ ratios tend to be followed by falls in share prices over the next 10 years. In this sense, the $\mathrm{P} / \mathrm{E}$ ratio gives an indication of the fundamental 
value of shares and can be used to predict long run share market performance. ${ }^{8}$ The evidence also gives weight to arguments that low P/E ratios in the late 1970s indicated that the market was underpriced; and that the recent record high values signalled an overvalued share market that was headed for a substantial correction. ${ }^{9}$

It has been argued recently that share-price behaviour of the 1990s has been unusual with the implication that there has perhaps been a shift in the long-term $\mathrm{P} / \mathrm{E}$ ratio (amongst other things). There has, however, been no convincing explanation of why this shift has occurred, with most analyses managing to explain only a part of the long bull run in the past decade. Campbell and Shiller (2001, p. 12) articulate this argument well by outlining a number of the ways the US economy has changed during the twentieth century. They note that throughout all innovations in transport, communication and business, the $\mathrm{P} / \mathrm{E}$ and $\mathrm{D} / \mathrm{P}$ ratios have stayed remarkably stable. There is no reason to think that the 'new economy' warrants a permanent break from the long-term relationship between prices, earnings and dividends. Perhaps the most compelling evidence of this can be seen by observing the dramatic falls in the stock market since early 2001, bringing valuation ratios more in line with historical averages. Figure 6 shows the annual values for the P/E ratio for the S\&P500 taken from Robert Shiller's web-site. ${ }^{10}$

\section{[Figure 6 near here]}

This evidence shows that over a long period the $\mathrm{P} / \mathrm{E}$ ratio fluctuated substantially over time, but tends to gravitate towards its mean of around 14 . Two periods where the $\mathrm{P} / \mathrm{E}$ ratio has deviated substantially from the trend are the time leading up to the great depression and the period before the substantial correction on world equity markets in early 2001. This further supports the proposition that the ratio does not deviate from its mean indefinitely.

Given these data and the unresolved nature of the debate, we use the assumed long-term constancy of the $\mathrm{P} / \mathrm{E}$ ratio to estimate fundamental share prices. Since we have no information on the "normal" level of $\mathrm{P} / \mathrm{E}$, we use the long-term average taken from Shiller's data and compute fundamentals, $P^{*}$, as:

\footnotetext{
${ }^{8}$ Blielberg (1989, p. 31) notes that this predictive power cannot be used to time the market because an overvalued market can 'do well' for a long time. Rather the P/E ratio can be used as a mild indicator of the likely changes in share returns over the next several years.

${ }^{9}$ See for example Kopcke (1997), White (2000) and Cole, Helwege and Laster (1996) for further discussion of this argument.

${ }^{10}$ At http://aida.econ.yale.edu/ shiller
} 


$$
P_{t}^{*}=\left(\frac{P}{E}\right)^{\text {average }} \times E_{t}
$$

where E represents earnings. Figure 7 plots the log of real fundamental and actual share prices over the period based on this procedure. The graph supports many commonly held beliefs regarding share price behaviour over the last three decades. Firstly, we can see a period of undervaluation during the second half of the 1970s and the early 1980s. The 1990s, characterized by strong economic growth and an emerging 'equity culture', represents a decade of persistent overvaluation of the S\&P 500.

\section{[Figure 7 near here]}

We next use the generated fundamental values in log first difference form in the VAR equation for investment. Speculative returns, $\Delta \ln S p e c$, are defined as: $\Delta \ln S P I-\Delta \ln$ Fund . Results are presented in the second set of columns of Table 5.

The magnitudes of the coefficients and their t-ratios for the speculative terms are not greatly different from those based on the previous decomposition using the regression of share prices on fundamental variables, with two of the three speculative lags significant at $10 \%$. In contrast to the previous case, however, one of the fundamentals lags is also significant and has a much larger coefficient than it had in the previous case. This difference is reflected in the values of the Wald statistics for the joint significance each of the sets of regressors which indicate that each set of variables is now jointly significant. Moreover, the coefficients of the second lagged terms are now significantly different at the $10 \%$ level.

This difference between the results based on the $\mathrm{P} / \mathrm{E}$ ratio and those obtained from the regression-based decomposition carries through to the IRFs shown in Figure 8 where we see that, compared to the previous case, the shock to the speculative component is of similar shape but with a smaller peak while the fundamentals component now has an effect more like that of the speculative component. Nevertheless, it is still the case that the speculative component of share prices has a significant positive effect on investment.

\section{[Figure 8 near here]}




\subsubsection{Fundamentals Based on the Dividend Yield}

The same process can be followed using other financial ratios such as the dividend yield. In this case we take the long-term dividend yield and calculate the implied fundamental series from the contemporaneous dividends:

$$
P_{t}^{*}=\left(\frac{P}{D}\right)^{\text {average }} \times D_{t}
$$

Where D represents dividends. Clearly the same arguments apply to this approach as to the previous one; in particular, there have been arguments along the same lines that there must have been a long-term shift in the dividend yield to explain the magnitude and duration of the 1990s bull market. The Shiller long-term data show an average yield of $4.79 \%$ over the period although there is considerable fluctuation between $1.3 \%$ and $7.2 \%$. We use the long-term average in equation (4) to compute the fundamental share price, producing the results illustrated in Figure 9.

\section{[Figure 9 near here]}

The fundamental series based on dividends has shown little change over the period, with only a slight upward trend during the 1990s. However, on closer examination we can see that many changes in the fundamental price index are accompanied by a change in the actual price index, with the change in the actual price index generally being more pronounced. This decomposition illustrates several hypotheses in finance; e.g., the excess volatility argument of Shiller (1981). It is also supportive of the overreaction hypothesis in behavioural finance theory, where share prices respond to relevant economic news, but to a degree not justified by fundamentals. ${ }^{11}$ The graph indicates that the S\&P 500 has been over-valued since the mid-1980s with the share market crash of 1987 not having a significant impact on this trend. Substantial overvaluation begins during the mid-1990s.

In the investment equation speculative share returns are again defined as the difference between actual and warranted share returns. The regression results, reported in the third set of columns in Table 5 are quite similar to the $\mathrm{P} / \mathrm{E}$ based decomposition in terms of significance and magnitude of the coefficients. This similarity is surprising given the difference in the graphs of fundamentals derived from the two approaches. This similarity is carried through to the IRFs in Figure 10 although the effects of the speculative shock are more dominant in the present case.

\footnotetext{
${ }^{11}$ See Campbell (2000) for a general reference; more specifically, Shefrin and Statman (2000) and, critically, Fama (1998).
} 


\section{[Figure 10 hereabouts ]}

\subsubsection{Fundamentals Based on the Black et al.(2001) Decomposition}

Black et al. (2001) develop a model based on the present-value relationship between share prices and output and use a linearised version of this relationship to impose restrictions on a VAR model involving share returns and output growth (and in some versions, the discount rate). The model builds on the work of Campbell and Shiller (1987, 1988) and Chung and Lee (1998), who study the relationship between share prices and dividends. The Black et al. approach is based on a model with CobbDouglas production technology and perfect competition although it is shown to be applicable under more general technology and market structure assumptions. The model output is a fundamental value of the output-share-price ratio which is combined with actual output to generate a time-series for the fundamental share price, in the same manner as we used the "fundamental" $\mathrm{P} / \mathrm{E}$ and $\mathrm{D} / \mathrm{P}$ ratios above combined with actual $\mathrm{E}$ and $\mathrm{D}$ respectively.

Figure 11 reproduces the first graph in their paper (under the constant required rate of return scenario). ${ }^{12}$

\section{[Figure 11 about here]}

It illustrates three broad periods of over- and under-valuation of the S\&P 500, not dissimilar to the long run $\mathrm{P} / \mathrm{E}$ based method.

The incorporation of the fundamental and speculative components into the investment equation is somewhat problematical in the present case since, when they are included with the other determinants, there is near perfect multicollinearity, making it impossible to estimate the coefficients at all accurately. This occurs because the equation generating the fundamental component in the Black et al. model has the form:

$$
\Delta \ln S P^{F_{t}}=k_{1}\left(\Delta \ln S P_{t}-\Delta \ln Y_{t}\right)+k_{2} \Delta^{2} \ln Y_{t}+\Delta \ln Y_{t}
$$

where $\Delta \ln S P^{F}$ denotes the fundamental component of share returns, $k_{1}$ and $k_{2}$ are constants determined by the model and $\Delta^{2}$ is the second difference operator. ${ }^{13}$ The speculative component is then given by

\footnotetext{
${ }^{12}$ They estimate three different models, depending on whether the required return is assumed to be constant or generated using a time-varying risk premium or a time-varying risk-free rate. We use only the version with a constant required rate of return in this study since the general shape of the fundamentals graph is the same under all three assumptions.
} 


$$
\Delta \ln S P_{t}^{S}=\Delta \ln S P_{t}-\Delta \ln S P^{F}{ }_{t}
$$

and clearly only the presence of $\Delta^{2} \ln Y_{t}$ in the expression for $\Delta \ln S P^{F}$ and $\Delta \ln S P^{S}$ avoids prefect multicollinearity between $\Delta \ln S P^{F}, \Delta \ln S P^{S}$ and $\Delta \ln Y$. Since $\Delta^{2} \ln Y$ carries little additional information, the three variables are close to perfect multicollinearity - the regression of the first on the other two produces a value for $\mathrm{R}^{2}$ of $97 \%$ and the inclusion of all three variables in the equation results in many standard errors of the order of $0.5 \times 10^{18}$. We therefore omitted one of the three variables and since our focus is on the separate roles of speculative and fundamental components of share prices, we report the investment equation in Table 5 with the output growth variable omitted. ${ }^{14}$ This is not without cost, however, since it means that the investment equation is not strictly comparable to the others in the table and it is likely that the effect of the fundamental component will be exaggerated since previous results suggest that there is considerable overlap between the effects on investment of output growth and the fundamental component of share prices. We check this conjecture by re-running the other regressions in the table without the output variables.

We can see that using the Black et al. decomposition of share prices, the coefficients of the fundamental terms are noticeably larger than in the previous equation, although only the third lag is marginally significant. None of the speculative terms is significant. The IRFs reported in Figure 12 reflect these features of the regression equation.

\section{[Figure 12 near here]}

The graph shows that the reaction to fundamental and speculative shocks is very similar in direction, but fundamentals have a greater impact. The effect of both shocks reaches zero after two years and fades out completely by the fifteenth quarter. These results differ from the results obtained from previous models but they are more in line with the findings of Blanchard et al. (1993) who reported a more important role for fundamentals in the investment process.

The magnitude of the coefficients of the fundamental components suggests that they are picking up at least some of the effects of the omitted output variables.

\footnotetext{
${ }^{13}$ In our application $\mathrm{k}_{1}=0.2196$ and $\mathrm{k}_{2}=0.3013$.

${ }^{14}$ We used a simpler model to test the restrictions that real output growth affects investment only through its role in the two components of share returns but the restriction was rejected so that real output growth has a dual role - a determinant of investment both directly and through its effect on fundamentals.
} 
We checked this conjecture by re-running the other three equations in Table 5 with the output variables omitted. These results are reported in Table 6. Surprisingly, there is no evidence to support our conjecture - there is little loss of explanatory power and the inferences drawn from the equations is similar. For the equation based on the regression decomposition, all three fundamental terms are insignificant as before and for the equations based on the $\mathrm{P} / \mathrm{E}$ and $\mathrm{D} / \mathrm{P}$ decompositions, the magnitude of the estimated coefficients and the t-ratios are generally little affected by the omission of output growth. These results are confirmed by the IRFs (not reported) generated from the VAR model with output growth excluded which have a very similar shape to those generated by the model including output growth. We can conclude that the larger coefficients in the equation based on the Black et al. decomposition simply reflects the different decomposition method rather than the omission of output growth from the investment equation.

\section{[Table 6 about here]}

\section{Conclusions}

This paper has used US data to investigate the effects of share price movements on investment. We found in a simple regression of investment on lagged share returns that returns have significant predictive power for investment. Moreover, this effect did not disappear when the equation was extended to include determinants of investment other share returns.

We extended the analysis by distinguishing between fundamental and speculative components of share returns in order to test whether there is a difference in managers' reactions to share price movements which are simply speculative and transitory. Since these two components are not directly observable, they must be generated from a model of share-price fundamentals. Such models are not uncontroversial so that we experimented with four alternatives: (a) a regression-based decomposition; (b) a decomposition based on an assumed constant long-term priceearnings ration; (c) a decomposition based on an assumed constant long-term dividend yield and (d) a decomposition based on a linearised macroeconomic dividend-discount model taken from Black et al. (2001) and based on earlier work by Campbell and Shiller $(1987,1988)$. The first three models produced rather similar results that speculative components were more important than fundamentals but these results were reversed for the last model which showed that fundamental share price 
movements are more important for investment behaviour, although it is possible that in the fourth case the effect of fundamentals may be exaggerated due to the omission of output growth from the investment equation.

We can conclude that in general speculative components of share prices have a positive effect on investment which is at least as large as that of fundamentals when other, more traditional, determinants of investment have been controlled for. 


\section{References}

Aggarwal, R. and D. C. Schirm (1992), 'Balance of Trade Announcements and Asset Prices: Influence on Equity Prices, Exchange Rates and Interest Rates', Journal of International Money and Finance, 11, pp. 80-95.

Anderson, M. and R. Subbaraman (1996), "Share prices and Investment", Reserve Bank of Australia Discussion Paper 9610.

Balduzzi, P. (1995), 'Stock Returns, Inflation and the 'Proxy Hypothesis': A New Look at the Data', Economics Letters, 48, pp. 47-53.

Barro, R. J. (1990), "The Stock Market and Investment", Review of Financial Studies 3, 115-131.

Black, A., P. Fraser and N. Groenewold (2001), "US Stock Prices and Macroeconomic Fundamentals", Department of Economics Discussion Paper 01-08, University of Western Australia.

Blanchard, O. J., C. Rhee and L. Summers (1993), 'The Stock Market, Profit and Investment' Quarterly Journal of Economics, 108, pp. 115-136.

Blielberg, S. (1989), "How Little We Know”, Journal of Portfolio Management, 16, 26-31.

Bodie Z. (1976), 'Common Stocks as a Hedge against Inflation', Journal of Finance, 31, pp. 459-470.

Bosworth, B.P. (1975), “The Stock Market and the Economy”, Brookings Papers on Economic Activity 2, 257-300

Breeden, D. (1979), 'An Intertemporal Asset Pricing Model with Stochastic Investment and Consumption Opportunities', Journal of Financial Economics, 7, pp. 265-296.

Campbell, J. Y. (2000), “Asset Pricing at the Millennium”, Journal of Finance, 55, 1515-1567.

Campbell, J. Y. and J. Ammer (1993), 'What Moves the Stock and Bond Markets? A Variance Decomposition for Long-Term Asset Returns', Journal of Finance, 48, pp. 3-37.

Campbell, J. Y. and R. J. Shiller (1987), 'Cointegration and Tests of Present Value Models', Journal of Political Economy, 95, pp. 062-1088.

Campbell, J. Y. and R. J. Shiller (1988), 'Stock Prices, Earnings and Expected Dividends', Journal of Finance, 43, pp. 661-676. 
Campbell, J. Y. and R. J. Shiller (1998), "Valuation Ratios and the Long-Run Stock Market Outlook", Journal of Portfolio Management 24, 11-27

Campbell, J. Y. and R. J. Shiller (2001), "Valuation Ratios and the Long-Run Stock Market Outlook: An Update", National Bureau of Economic Research Working Paper 8221.

Chen, N., R. Roll and S. A. Ross (1986), 'Economic Forces and the Stock Market', Journal of Business, 59, pp. 383-403.

Chirinko, R.S. (1993), “Business Fixed Investment Spending: Modelling Strategies, Empirical Results, and Policy Implications", Journal of Economic Literature 31, 1875-1911.

Chirinko, R. S. and H. Schaller (1996), 'Bubbles, Fundamentals and Investment: A Multiple Equation Testing Strategy', Journal of Monetary Economics, 38, pp. 47-76.

Chung, H. and B.-S. Lee (1998), 'Fundamental and Nonfundamental Components in Stock Prices of Pacific-Rim Countries', Pacific-Basin Journal of Finance, 6, pp. 321-346.

Cochrane, J.H. (1991), Production-Based Asset Pricing and the Link Between Stock Returns and Economic Fluctuations”, Journal of Finance 46, 209-237.

Cole, K., J. Helwege and D. Laster (1996), "Stock Market Valuation Indicators: Is This Time Different?", Financial Analysts Journal May/June, 56-64.

Doan, T., R. Litterman and C. Sims (1983), "Forecasting and Conditional Projection using Realistic Prior Distributions”, NBER Working Paper 1202.

Fama, E. F. and G. W. Schwert, (1977), 'Asset Returns and Inflation', Journal of Financial Economics, 5, pp.115-146.

Fama, E. F. (1998), "Market Efficiency, Long-Term returns and Behavioural Finance”, Journal of Financial Economics, 49, 283-306.

Fischer, S. and R. C. Merton (1984), 'Macroeconomics and Finance: The Role of the Stock Market', Carnegie-Rochester Conference Series on Public Policy, 21, pp. 57-108.

Galeotti, M. and F. Schiantarelli (1994), "Stock Market Volatility and Investment: Do only Fundamentals Matter?", Economica 61, 147-165.

Gilchrist, S. and J. V. Leahy (2002), "Monetary Policy and Asset Prices”, Journal of Monetary Economics, 49, 75-97. 
Graham, F. C. (1996), 'Inflation, Real Stock Returns and Monetary Policy', Applied Financial Economics, 6, pp. 29-35.

Grossman, S. and R. Shiller (1981), 'The Determinants of the Variability of Stock Market Prices', American Economic Review, 71, pp. 222-227.

Jaffe, J. and G. Mandelker, (1976), 'The 'Fisher Effect' for Risky Assets: An Empirical Investigation', Journal of Finance, 31, pp. 447-458.

Jain, P. C. (1988), 'Response of Hourly Stock Prices and Trading Volume to Economic News', Journal of Business, 61, pp. 219-231.

Johansen, S. (1988), "Statistical Analysis of Cointegration Vectors", Journal of Economic Dynamics and Control, 231-254.

Johansen, S. and Juselius, K. (1990), "Maximum Likelihood Estimation and Inference on Cointegration - with Applications to the Demand for Money", Oxford Bulletin of Economics and Statistics, 169-210.

Jorgenson, D. W. (1971), "Econometric Studies of Investment Behaviour: A Survey", Journal of Economic Literature 9, 1111-47.

Koop, G., M.H. Pesaran and S.M. Potter (1996), "Impulse Response Analysis in Nonlinear Multivariate Models", Journal of Econometrics 74, 119-147

Kopcke, R.W. (1997), “Are Stocks Overvalued?”, New England Economic Review Sept/Oct, 21-40.

Lamont, O.A. (2000), "Investment Plans and Stock Returns", Journal of Finance 55, 2719-2745.

McAleer, M., and C.R. McKenzie (1991), "When are Two Step Estimators Efficient?", Econometric Reviews 10, 235-252.

Morck, R., A. Schleifer and R. W. Vishny (1990), 'The Stock Market and Investment: Is the Market a Sideshow?', Brookings Papers on Economic Activity 2, pp. 157-215.

Mullins, M., and S.B Wadhwani (1989), "The Effect of the Stock Market on Investment: A Comparative Study", European Economic Review 33, 939961.

Nelson, C. R., (1976), 'Inflation and Rates of Return on Common Stock', Journal of Finance, 31, pp. 471-483.

Oxley, L., and M. McAleer (1993), "Econometric Issues in Macroeconomic Models with Generated Regressors”, Journal of Economic Surveys 7, 1-40. 
Pagan, A. (1984), "Econometric Issues in the Analysis of Regressions with Generated Regressors”, International Economic Review 25, 221-247.

Pearce, D. K. and V. V. Roley (1985), 'Stock Prices and Economic News', Journal of Business, 58, pp. 49-67.

Pesaran, M.H., and Y. Shin (1998), “Generalised Impulse Response Analysis in Linear Multivariate Models", Economic Letters 58, 17-29.

Poterba, J. and A. Samwick (1995), "Stock Ownership Patterns, Stock Market Fluctuations and Consumption", Brookings Papers in Economic Activity, No.2, 295-372.

Shefrin, H. and M. Statman (2000), "Behavioural Portfolio Theory", Journal of Financial and Quantitative Analysis, 35, 127-151.

Shiller R. J. (1981), "Do Stock Prices Move too Much to be Justified by Subsequent Changes in Dividends?”, American Economic Review, 71, 421-436.

Siklos, P. and B. Kwok (1999), 'Stock Returns and Inflation: A New Test of Competing Hypotheses', Applied Financial Economics, 9, pp. 567-581.

Singh, R. A. (1993), 'Response of Stock Prices to Money Supply Announcements: Australian Evidence', Accounting and Finance, 33, pp. 43-59.

Starr-McCluer, M. (2002), "Stock Market Wealth and Consumer Spending", Economic Inquiry, 40, 69-79.

Tobin, J. (1969), ‘A General Equilibrium Approach to Monetary Theory’, Journal of Money, Credit and Banking, 1, pp. 15-29.

White, C.B. (2000), "What P/E Ratio Will the US Stock Market Support?", Financial Analyst's Journal 56, 30-38. 
Table 1. Summary Statistics*

\begin{tabular}{lcccccccc}
\hline Variable & Mean & S.D. & J-B & AR(1) & AR(2) & AR(3) & AR(4) & Q(4) \\
\hline$\Delta \operatorname{lnI}$ & 0.078 & 0.024 & 19.984 & 0.489 & 0.317 & 0.142 & 0.031 & 69.059 \\
& & & $(0.000)$ & $(0.073)$ & $(0.089)$ & $(0.095)$ & $(0.096)$ & $(0.000)$ \\
$\Delta \ln S P I$ & 0.012 & \multirow{2}{*}{0.079} & 72.706 & 0.105 & -0.064 & 0.010 & 0.017 & 2.952 \\
& & & $(0.000)$ & $(0.073)$ & $(0.074)$ & $(0.074)$ & $(.074)$ & $(0.566)$ \\
$\Delta \ln \pi$ & 0.006 & \multirow{2}{*}{0.076} & 54.624 & 0.101 & 0.045 & 0.002 & -0.034 & 2.584 \\
& & & $(0.000)$ & $(0.073)$ & $(0.074)$ & $(0.074)$ & $(0.074)$ & $(0.630)$ \\
$\Delta \operatorname{lnGDP}$ & 0.008 & \multirow{2}{*}{0.010} & 13.658 & 0.342 & 0.181 & 0.027 & -0.0608 & 29.554 \\
& & & $(0.001)$ & $(0.073)$ & $(0.081)$ & $(0.083)$ & $(0.083)$ & $(0.000)$ \\
Yield & \multirow{2}{*}{0.007} & \multirow{2}{*}{0.007} & 9.628 & 0.796 & 0.720 & 0.721 & 0.607 & 394.603 \\
& & & $(0.008)$ & $(0.073)$ & $(0.110)$ & $(0.132)$ & $(0.152)$ & $(0.000)$ \\
\multirow{2}{*}{$\operatorname{lnCPI}$} & \multirow{2}{*}{0.010} & \multirow{2}{*}{0.008} & 65.326 & 0.836 & 0.768 & 0.769 & 0.679 & 453.110 \\
& & & $(0.000)$ & $(0.073)$ & $(0.113)$ & $(0.138)$ & $(0.159)$ & $(0.000)$ \\
\hline
\end{tabular}

* $\Delta \operatorname{lnI}$ is the $\log$ first difference in real private non-residential fixed investment; $\Delta \operatorname{lnSPI}$ is $\log$ first difference in the S\&P 500 composite index; $\Delta \ln \pi$ is the $\log$ first difference in real profits after tax; $\Delta \operatorname{lnGDP}$ is the $\log$ first difference in constant dollar GDP; Yield is the real 10 -year treasury yield; $\Delta \operatorname{lnCPI}$ is the inflation rate. J-B is the Jarque-Bera test for normality. The AR(.) are autocorrelation coefficients at lags 1-4. The Q(4) statistic is the Ljung-Box test statistic for joint significance of the first 4 autocorrelation coefficient. Figures in parentheses below the autocorrelation coefficients are standard errors and under the J-B and $\mathrm{Q}(4)$ are marginal significance levels.

Table 2. Stationarity Test of Variables in the Investment Equation*

\begin{tabular}{|c|c|c|c|c|c|c|c|c|c|c|}
\hline & \multicolumn{2}{|c|}{$\ln I$} & \multicolumn{2}{|c|}{ InSPI } & \multicolumn{2}{|c|}{$\ln \pi$} & \multicolumn{2}{|c|}{ InGDP } & \multicolumn{2}{|c|}{ Yield } \\
\hline (A) & Trend & $\begin{array}{c}\text { No } \\
\text { Trend }\end{array}$ & Trend & $\begin{array}{c}\text { No } \\
\text { Trend }\end{array}$ & Trend & $\begin{array}{c}\text { No } \\
\text { Trend }\end{array}$ & Trend & $\begin{array}{c}\text { No } \\
\text { Trend }\end{array}$ & Trend & $\begin{array}{c}\text { No } \\
\text { Trend }\end{array}$ \\
\hline DF & -1.01 & 0.87 & -0.61 & -0.03 & -2.24 & -1.51 & -1.93 & -0.74 & -4.88 & -4.53 \\
\hline $\mathrm{ADF}(1)$ & -2.47 & 0.22 & -0.86 & -0.29 & -2.59 & -1.71 & -2.53 & -0.64 & -3.63 & -3.35 \\
\hline $\operatorname{ADF}(2)$ & -2.91 & 0.08 & -0.68 & -0.11 & -2.73 & -1.77 & -2.75 & -0.64 & -2.63 & -2.44 \\
\hline $\mathrm{ADF}(3)$ & -2.76 & 0.17 & -0.74 & -0.17 & -2.76 & -1.77 & -2.64 & -0.63 & -3.07 & -2.82 \\
\hline $\operatorname{ADF}(4)$ & -2.63 & 0.23 & -0.77 & -0.19 & -2.71 & -1.71 & -2.48 & -0.61 & -3.31 & -3.03 \\
\hline & & & & SPI & & & $\Delta \ln$ & DP & & \\
\hline (B) & Trend & $\begin{array}{c}\text { No } \\
\text { Trend }\end{array}$ & Trend & $\begin{array}{l}\text { No } \\
\text { Trend }\end{array}$ & Trend & $\begin{array}{c}\text { No } \\
\text { Trend }\end{array}$ & Trend & $\begin{array}{c}\text { No } \\
\text { Trend }\end{array}$ & & \\
\hline DF & -7.88 & -7.86 & -12.29 & -12.26 & -11.72 & -11.75 & -9.65 & -9.67 & & \\
\hline $\mathrm{ADF}(1)$ & -5.98 & -5.95 & -9.89 & -9.84 & -8.52 & -8.54 & -7.21 & -7.22 & & \\
\hline $\mathrm{ADF}(2)$ & -5.82 & -5.78 & -7.84 & -7.78 & -7.16 & -7.18 & -6.68 & -6.69 & & \\
\hline $\mathrm{ADF}(3)$ & -5.72 & -5.67 & -6.74 & -6.67 & -6.53 & -6.55 & -6.44 & -6.45 & & \\
\hline $\operatorname{ADF}(4)$ & -5.82 & -5.76 & -6.10 & -6.02 & -6.87 & -6.89 & -6.75 & -6.76 & & \\
\hline
\end{tabular}

* InI is the log of real private non-residential fixed investment; InSPI is log of the S\&P 500 composite index; $\ln \pi$ is the $\log$ of real profits after tax; InGDP is the log of constant dollar GDP; Yield is the real 10-year treasury yield. The ADF regressions include an intercept and distinction is made between the inclusion and exclusion of a linear trend. The $\mathbf{9 5 \%}$ critical value for the AD regression with and without a trend is $\mathbf{- 3 . 7 4 8 1}$ and $-\mathbf{2 . 8 8 5 8}$ respectively. 
Table 3. Cointegration Test*

\begin{tabular}{|c|c|c|c|c|c|c|}
\hline Test & Trend & $\mathrm{H}_{0}$ & $\mathrm{H}_{1}$ & Statistic & $95 \%$ & $90 \%$ \\
\hline \multirow{4}{*}{$\begin{array}{l}\text { Max } \\
\text { Eigenvalue }\end{array}$} & \multirow{4}{*}{ No } & $\mathrm{r}=0$ & $\mathrm{r}=1$ & 18.4250 & 27.42 & 24.99 \\
\hline & & $r \leq 1$ & $r=2$ & 12.4639 & 21.12 & 19.02 \\
\hline & & $r \leq 2$ & $r=3$ & 2.5124 & 14.88 & 12.98 \\
\hline & & $r \leq 3$ & $r=4$ & 0.7346 & 8.07 & 6.50 \\
\hline \multirow[t]{4}{*}{ Trace } & \multirow[t]{4}{*}{ No } & $r=0$ & $r=1$ & 34.1359 & 48.88 & 45.70 \\
\hline & & $r \leq 1$ & $r=2$ & 15.7109 & 31.54 & 28.78 \\
\hline & & $r \leq 2$ & $r=3$ & 3.2470 & 17.86 & 15.75 \\
\hline & & $r \leq 3$ & $r=4$ & 0.7346 & 8.07 & 6.50 \\
\hline Max & \multirow{4}{*}{ Yes } & $\mathrm{r}=0$ & $\mathrm{r}=1$ & 17.0542 & 31.00 & 28.32 \\
\hline \multirow[t]{3}{*}{ Eigenvalue } & & $r \leq 1$ & $r=2$ & 15.6374 & 24.35 & 22.26 \\
\hline & & $r \leq 2$ & $r=3$ & 9.9553 & 18.33 & 16.28 \\
\hline & & $r \leq 3$ & $r=4$ & 0.4502 & 11.54 & 9.75 \\
\hline \multirow[t]{4}{*}{ Trace } & \multirow[t]{4}{*}{ Yes } & $\mathrm{r}=0$ & $\mathrm{r}=1$ & 43.0971 & 58.93 & 55.01 \\
\hline & & $r \leq 1$ & $r=2$ & 26.0429 & 39.33 & 36.28 \\
\hline & & $r \leq 2$ & $r=3$ & 10.4055 & 23.83 & 21.23 \\
\hline & & $r \leq 3$ & $r=4$ & 0.4502 & 11.54 & 9.75 \\
\hline
\end{tabular}

* Variables included in the cointegration tests are InI, the log of real private non-residential fixed investment; InSPI, the $\log$ of the $S \& P 500$ composite index; $\ln \pi$, the $\log$ of real profits after tax; $\ln G D P$, the log of constant dollar GDP. Cointegration tests are based on the maximal eigenvalue and trace of the stochastic matrix. Results are presented for unrestricted intercepts and both unrestricted trends and no trend in the VAR. $r$ is the number of cointegrating vectors. 
Table 4. Basic Investment Equations*

\begin{tabular}{|c|c|c|c|c|c|c|c|c|c|}
\hline & \multicolumn{3}{|c|}{ (1) } & \multicolumn{3}{|c|}{ (2) } & \multicolumn{3}{|c|}{ (3) } \\
\hline & Coeff & T-stat & Prob & Coeff & T-stat & Prob & Coeff & T-stat & Prob \\
\hline$\Delta \ln I(-1)$ & 0.3398 & 4.61 & 0.000 & 0.0756 & 1.52 & 0.130 & 0.0799 & 1.53 & 0.128 \\
\hline$\Delta \ln I(-2)$ & 0.1872 & 2.50 & 0.013 & 0.1352 & 1.33 & 0.185 & 0.1720 & 1.60 & 0.111 \\
\hline$\Delta \ln I(-3)$ & 0.0293 & 0.41 & 0.680 & -0.0329 & -0.35 & 0.725 & 0.0407 & 0.43 & 0.666 \\
\hline$\Delta \ln S P I(-1)$ & 0.0349 & 1.91 & 0.057 & - & - & - & 0.0297 & 2.16 & 0.032 \\
\hline$\Delta \ln S P I(-2)$ & 0.0869 & 4.78 & 0.000 & - & - & - & 0.0750 & 3.82 & 0.000 \\
\hline$\Delta \ln S P I(-3)$ & 0.0379 & 1.96 & 0.052 & - & - & - & 0.0196 & 1.10 & 0.272 \\
\hline$\Delta \ln \pi(-1)$ & - & - & - & 0.0749 & 3.51 & 0.001 & 0.0694 & 3.08 & 0.002 \\
\hline$\Delta \ln \pi(-2)$ & - & - & - & 0.0407 & 1.47 & 0.143 & 0.0528 & 2.57 & 0.011 \\
\hline$\Delta \ln \pi(-3)$ & - & - & - & -0.0445 & -3.07 & 0.002 & -0.0412 & -2.97 & 0.003 \\
\hline$\Delta \ln G D P(-1)$ & - & - & - & 0.6030 & 2.43 & 0.016 & 0.4267 & 1.63 & 0.105 \\
\hline$\Delta \ln G D P(-2)$ & - & - & - & 0.1823 & 0.72 & 0.469 & 0.0731 & 0.31 & 0.754 \\
\hline$\Delta \ln G D P(-3)$ & - & - & - & 0.5806 & 2.59 & 0.010 & 0.5098 & 2.60 & 0.010 \\
\hline Yield (-1) & - & - & - & 0.6258 & 2.43 & 0.016 & 0.3337 & 1.45 & 0.149 \\
\hline Yield (-2) & - & - & - & -0.8849 & -3.15 & 0.002 & -0.9216 & -3.09 & 0.002 \\
\hline Yield (-3) & - & - & - & 0.3968 & 1.09 & 0.276 & 0.4608 & 1.17 & 0.245 \\
\hline Intercept & 0.0040 & 2.27 & 0.025 & -0.0022 & -0.75 & 0.452 & -0.0003 & -0.14 & 0.891 \\
\hline R-bar ${ }^{2}$ & \multicolumn{3}{|c|}{0.34625} & \multicolumn{3}{|c|}{0.39131} & \multicolumn{3}{|c|}{0.44952} \\
\hline $\mathrm{R}^{2}$ & \multicolumn{3}{|c|}{0.36757} & \multicolumn{3}{|c|}{0.43100} & \multicolumn{3}{|c|}{0.49439} \\
\hline AC: CHSQ(4) & \multicolumn{3}{|c|}{$3.5905[0.464]$} & \multicolumn{3}{|c|}{11.8189 [0.019] } & \multicolumn{3}{|c|}{$8.3789[0.079]$} \\
\hline Heter: CHSQ(1) & \multicolumn{3}{|c|}{$0.0617[0.804]$} & \multicolumn{3}{|c|}{$3.9631[0.047]$} & \multicolumn{3}{|c|}{$1.9022[0.168]$} \\
\hline Wald Test: SPI & \multicolumn{3}{|c|}{$32.2955[0.000]$} & \multicolumn{3}{|c|}{-} & \multicolumn{3}{|c|}{$23.1007[0.000]$} \\
\hline
\end{tabular}

* The dependent variable is $\Delta \operatorname{lnI}$ and the variables are defined as : $\Delta \ln I$ is the log first difference in real private non-residential fixed investment; $\Delta \operatorname{lnSPI}$ is $\log$ first difference in the S\&P 500 composite index; $\Delta \ln \pi$ is the $\log$ first difference in real profits after tax; $\Delta \operatorname{lnGDP}$ is the log first difference in constant dollar GDP; Yield is the real 10-year treasury yield. Standard Errors are Newey-West heteroscedasticity and autocorrelation consistent estimates, adjusted using Parzen weights and a truncation lag of 30. AC is the statistic for a test of the joint significance of the first four autocorrelation coefficients for the residuals; Heter is the statistic for a test of ARCH(1) and Wald is a test for the joint significance of the three lags of the SPI variable. Figures in brackets are marginal significance levels. 
Table 5. Investment Equations With Fundamental and Speculative

Returns

\begin{tabular}{|c|c|c|c|c|c|c|c|c|c|}
\hline & \multicolumn{3}{|c|}{ OLS Regression } & \multicolumn{3}{|c|}{ Long Run P/E Ratio } & \multicolumn{3}{|c|}{ Long Run D/P Ra } \\
\hline & Coeff & T-stat & P-value & Coeff & T-stat & P-value & Coeff & T-stat & I \\
\hline$\Delta \ln I(-1)$ & 0.0003 & 0.00 & 0.998 & 0.0371 & 0.63 & 0.532 & 0.0487 & 0.46 & \\
\hline$\Delta \ln I(-2)$ & 0.2663 & 2.46 & 0.016 & 0.2549 & 3.09 & 0.003 & 0.2721 & 2.52 & \\
\hline$\Delta \ln I(-3)$ & 0.0610 & 0.60 & 0.548 & 0.0185 & 0.11 & 0.913 & 0.0416 & 0.40 & \\
\hline$\Delta \ln F u n d(-1)$ & 0.1786 & 1.29 & 0.198 & 0.0201 & 0.63 & 0.528 & 0.0071 & 0.18 & \\
\hline$\Delta \operatorname{lnFund}(-2)$ & -0.1012 & -0.98 & 0.330 & 0.1127 & 3.83 & 0.000 & 0.1062 & 2.52 & \\
\hline$\Delta \ln F u n d(-3)$ & -0.0560 & -0.75 & 0.454 & -0.0016 & -0.06 & 0.949 & -0.0202 & -0.48 & \\
\hline$\Delta \operatorname{lnSpec}(-1)$ & 0.0225 & 1.05 & 0.297 & 0.0181 & 1.28 & 0.204 & 0.0209 & 0.94 & \\
\hline$\Delta \operatorname{lnSpec}(-2)$ & 0.0765 & 3.53 & 0.001 & 0.0532 & 3.04 & 0.003 & 0.0489 & 2.16 & \\
\hline$\Delta \operatorname{lnSpec}(-3)$ & 0.0332 & 1.46 & 0.148 & 0.0323 & 2.20 & 0.030 & 0.0348 & 1.58 & \\
\hline$\Delta \ln \pi(-1)$ & 0.0779 & 2.99 & 0.004 & 0.0578 & 2.69 & 0.008 & 0.0620 & 2.46 & \\
\hline$\Delta \ln \pi(-2)$ & 0.0690 & 2.50 & 0.014 & 0.0562 & 1.97 & 0.051 & 0.0588 & 2.25 & \\
\hline$\Delta \ln \pi(-3)$ & -0.0237 & -0.91 & 0.367 & -0.0508 & -2.79 & 0.006 & -0.0521 & -2.07 & \\
\hline$\Delta \ln G D P(-1)$ & 0.3924 & 1.49 & 0.139 & 0.5392 & 2.36 & 0.020 & 0.5307 & 2.02 & \\
\hline$\Delta \ln G D P(-2)$ & 0.0448 & 0.17 & 0.867 & 0.1097 & 0.41 & 0.685 & 0.0564 & 0.21 & \\
\hline$\Delta \ln G D P(-3)$ & 0.7416 & 2.43 & 0.017 & 0.5425 & 2.24 & 0.027 & 0.5570 & 2.19 & \\
\hline Yield (-1) & 0.1168 & 0.20 & 0.838 & 0.4813 & 2.32 & 0.022 & 0.5982 & 1.51 & \\
\hline Yield (-2) & 0.4648 & 0.48 & 0.635 & -0.8919 & -2.52 & 0.013 & -1.0902 & -2.31 & \\
\hline Yield (-3) & -0.5646 & -0.77 & 0.446 & 0.2232 & 0.56 & 0.580 & 0.3209 & 0.83 & \\
\hline Intercept & -0.0018 & -0.56 & 0.575 & -0.0002 & -0.10 & 0.920 & -0.0005 & -0.18 & \\
\hline R-bar ${ }^{2}$ & \multicolumn{3}{|c|}{0.43584} & \multicolumn{3}{|c|}{0.44757} & \multicolumn{3}{|c|}{0.44954} \\
\hline $\mathrm{R}^{2}$ & \multicolumn{3}{|c|}{0.51708} & \multicolumn{3}{|c|}{0.52712} & \multicolumn{3}{|c|}{0.52881} \\
\hline AC: CHSQ(4) & \multicolumn{3}{|c|}{$7.7312[0.102]$} & \multicolumn{3}{|c|}{$10.1108[0.039]$} & \multicolumn{3}{|c|}{$8.8581[0.065]$} \\
\hline Heter: CHSQ(1) & \multicolumn{3}{|c|}{$.72213[0.395]$} & \multicolumn{3}{|c|}{$0.68376[0.408]$} & \multicolumn{3}{|c|}{$.32406[0.569]$} \\
\hline Wald test: Fund & \multicolumn{3}{|c|}{$1.8354[0.607]$} & \multicolumn{3}{|c|}{$20.2761[0.000]$} & \multicolumn{3}{|c|}{$9.5700[0.023]$} \\
\hline Wald test: Spec & \multicolumn{3}{|c|}{$14.1493[0.003]$} & \multicolumn{3}{|c|}{$15.6295[0.001]$} & \multicolumn{3}{|c|}{$7.3862[0.061]$} \\
\hline Spec-1=Fund -1 & \multicolumn{3}{|c|}{$1.2225[0.269]$} & \multicolumn{3}{|c|}{$.0050885[0.943]$} & \multicolumn{3}{|c|}{$.10695[0.744]$} \\
\hline Spec-2=Fund-2 & \multicolumn{3}{|c|}{$2.7855[0.095]$} & \multicolumn{3}{|c|}{$7.1910[0.007]$} & \multicolumn{3}{|c|}{$1.4857[0.223]$} \\
\hline Spec-3=Fund-3 & \multicolumn{3}{|c|}{$1.3080[0.253]$} & \multicolumn{3}{|c|}{$3.5952[0.058]$} & & $1.7551[0.185]$ & \\
\hline$\Sigma$ Spec $=\Sigma$ Fund & & $1.1263[0.289]$ & & & $.3669[.5$ & & & $0.0132[0.908]$ & \\
\hline
\end{tabular}

*The dependent variable is $\Delta \operatorname{lnI}$ and the variables are defined as : $\Delta \ln I$ is the log first difference in real private non-residential fixed investment; $\Delta \operatorname{lnSPI}$ is $\log$ first difference in the S\&P 500 composite index; $\Delta \ln \pi$ is the $\log$ first difference in real profits after tax; $\Delta \operatorname{lnGDP}$ is the log first difference in constant dollar GDP; Yield is the real 10-year treasury yield. Standard Errors are Newey-West heteroscedasticity and autocorrelation consistent estimates, adjusted using Parzen weights and a truncation lag of 30 . AC is the statistic for a test of the joint significance of the first four autocorrelation coefficients for the residuals; Heter is the statistic for a test of $\mathrm{ARCH}(1)$ and the Wald statistics are for tests of the joint significance of the three lags of the Fund and Spec variables. Spec-i=Fund-i rows contain t-ratios and p-values for tests of equality of coefficients of corresponding lags of speculative and fundamental components. The $\Sigma$ Spec $=\Sigma$ Fund row contains t-ratios for a test of equality of the sum of the coefficients of the fundamental and speculative components. Figures in brackets are marginal significance levels. 
Table 6. Investment Equations With Fundamental and Speculative

Returns (GDP omitted)

\begin{tabular}{|c|c|c|c|c|c|c|c|c|}
\hline & \multicolumn{3}{|c|}{ OLS Regression } & \multicolumn{3}{|c|}{ Long Run P/E Ratio } & \multicolumn{2}{|c|}{ Long Run D/P Ra } \\
\hline & Coeff & T-stat & P-value & Coeff & T-stat & P-value & Coeff & T-stat \\
\hline$\Delta \ln I(-1)$ & 0.0998 & 1.01 & 0.314 & 0.1627 & 1.66 & 0.099 & 0.1662 & 1.71 \\
\hline$\Delta \ln I(-2)$ & 0.2971 & 3.09 & 0.003 & 0.2973 & 3.07 & 0.003 & 0.3022 & 3.14 \\
\hline$\Delta \ln I(-3)$ & 0.1431 & 1.49 & 0.140 & 0.1337 & 1.31 & 0.194 & 0.1428 & 1.49 \\
\hline$\Delta \operatorname{lnFund}(-1)$ & -0.0055 & -0.05 & 0.963 & 0.0216 & 0.69 & 0.489 & 0.0065 & 0.16 \\
\hline$\Delta \operatorname{lnFund}(-2)$ & 0.0157 & 0.17 & 0.867 & 0.1145 & 3.77 & 0.000 & 0.1053 & 2.44 \\
\hline$\Delta \ln F u n d(-3)$ & -0.0376 & -0.50 & 0.621 & -0.0017 & -0.05 & 0.959 & -0.0121 & -0.29 \\
\hline$\Delta \operatorname{lnSpec}(-1)$ & 0.0317 & 1.47 & 0.144 & 0.0247 & 1.12 & 0.266 & 0.0269 & 1.20 \\
\hline$\Delta \operatorname{lnSpec}(-2)$ & 0.0859 & 4.00 & 0.000 & 0.0707 & 3.31 & 0.001 & 0.0655 & 2.93 \\
\hline$\Delta \operatorname{lnSpec}(-3)$ & 0.0449 & 1.99 & 0.049 & 0.0394 & 1.77 & 0.079 & 0.0429 & 1.94 \\
\hline$\Delta \ln \pi(-1)$ & 0.0863 & 3.57 & 0.001 & 0.0742 & 3.13 & 0.002 & 0.0767 & 3.24 \\
\hline$\Delta \ln \pi(-2)$ & 0.0711 & 2.74 & 0.007 & 0.0645 & 2.53 & 0.013 & 0.0640 & 2.57 \\
\hline$\Delta \ln \pi(-3)$ & -0.0058 & -0.23 & 0.821 & -0.0265 & -1.09 & 0.278 & -0.0261 & -1.11 \\
\hline Yield (-1) & 0.5241 & 0.94 & 0.350 & 0.3797 & 0.95 & 0.347 & 0.4907 & 1.21 \\
\hline Yield (-2) & -0.5278 & -0.59 & 0.559 & -0.7391 & -1.57 & 0.120 & -0.9153 & -1.92 \\
\hline Yield (-3) & 0.3544 & 0.54 & 0.592 & 0.2904 & 0.74 & 0.459 & 0.3804 & 0.97 \\
\hline Intercept & 0.0021 & 0.77 & 0.441 & 0.0040 & 1.56 & 0.122 & 0.0037 & 1.43 \\
\hline R-bar ${ }^{2}$ & \multicolumn{3}{|c|}{0.41119} & \multicolumn{3}{|c|}{0.41998} & \multicolumn{2}{|r|}{0.41986} \\
\hline $\mathrm{R}^{2}$ & \multicolumn{3}{|c|}{0.48185} & \multicolumn{3}{|c|}{0.48959} & \multicolumn{2}{|r|}{0.48948} \\
\hline AC: CHSQ(4) & \multicolumn{3}{|c|}{$5.4947[0.240]$} & \multicolumn{3}{|c|}{$7.6169[0.107]$} & \multicolumn{2}{|r|}{$6.4307[0.169]$} \\
\hline Heter: CHSQ(1) & \multicolumn{3}{|c|}{$0.66142[0.416]$} & \multicolumn{3}{|c|}{$0.43668[0.509]$} & \multicolumn{2}{|r|}{$0.25241[0.615]$} \\
\hline Wald test: Fund & \multicolumn{3}{|c|}{$0.30132[0.960]$} & \multicolumn{3}{|c|}{$14.4752[0.002]$} & \multicolumn{2}{|r|}{$8.4357[0.038]$} \\
\hline Wald test: Spec & \multicolumn{3}{|c|}{$20.6898[0.000]$} & \multicolumn{3}{|c|}{$15.8248[0.001]$} & \multicolumn{2}{|r|}{$13.5800[0.004]$} \\
\hline Spec-1=Fund-1 & \multicolumn{3}{|c|}{$0.092927[0.760]$} & \multicolumn{3}{|c|}{$0.010557[0.918]$} & \multicolumn{2}{|r|}{$0.22420[0.636]$} \\
\hline Spec-2=Fund-2 & \multicolumn{3}{|c|}{$0.51953[0.471]$} & \multicolumn{3}{|c|}{$2.6084[0.106]$} & \multicolumn{2}{|r|}{$0.70491[0.401]$} \\
\hline Spec-3=Fund-3 & \multicolumn{3}{|c|}{$1.0772[0.299]$} & \multicolumn{3}{|c|}{$2.4765[0.116]$} & \multicolumn{2}{|r|}{$1.7830[0.182]$} \\
\hline$\Sigma$ Spec $=\Sigma$ Fund & \multicolumn{3}{|c|}{$3.4395[0.064]$} & & $0006[0.9$ & & & $0.12396[0.725]$ \\
\hline
\end{tabular}

\footnotetext{
* See notes to Table 5.
} 
Figure 1. - Real Share Prices and Real Investment

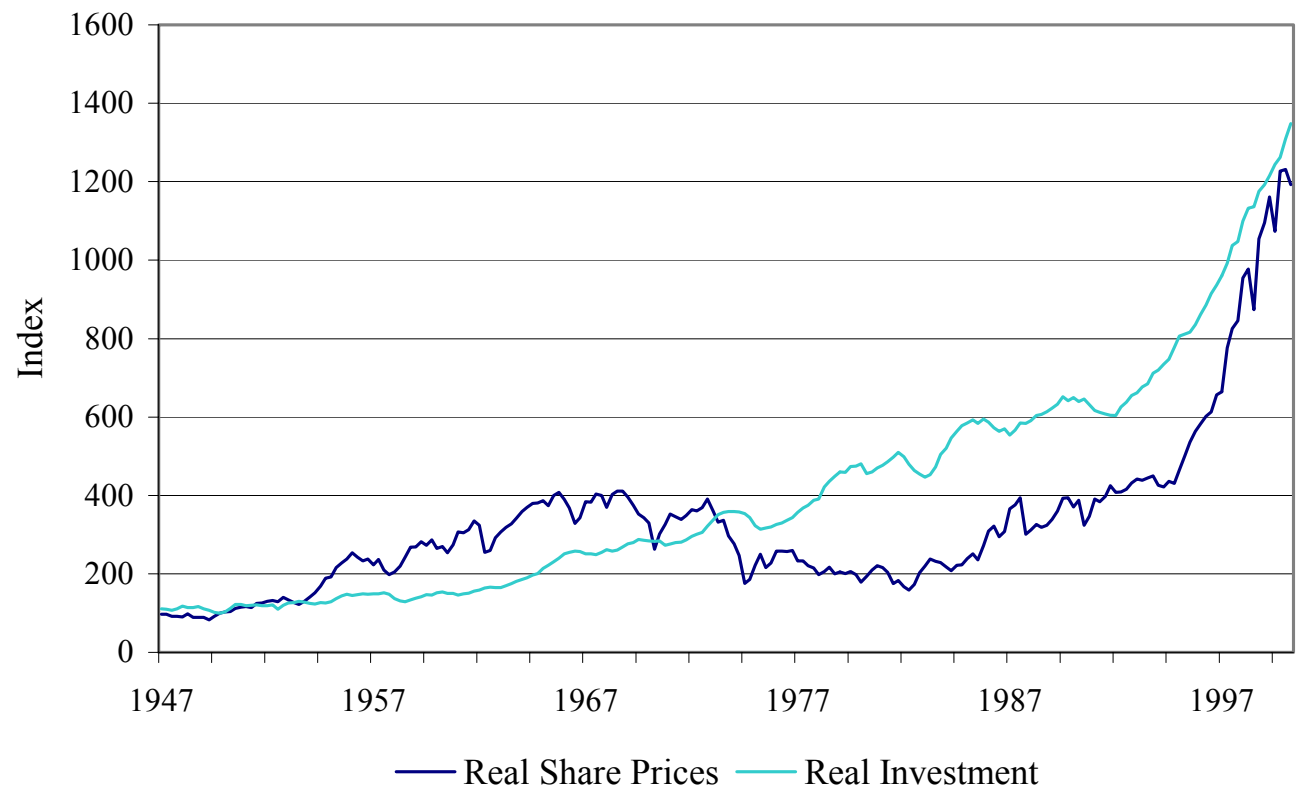

Figure 2. - Real Share Returns and Real Investment Growth

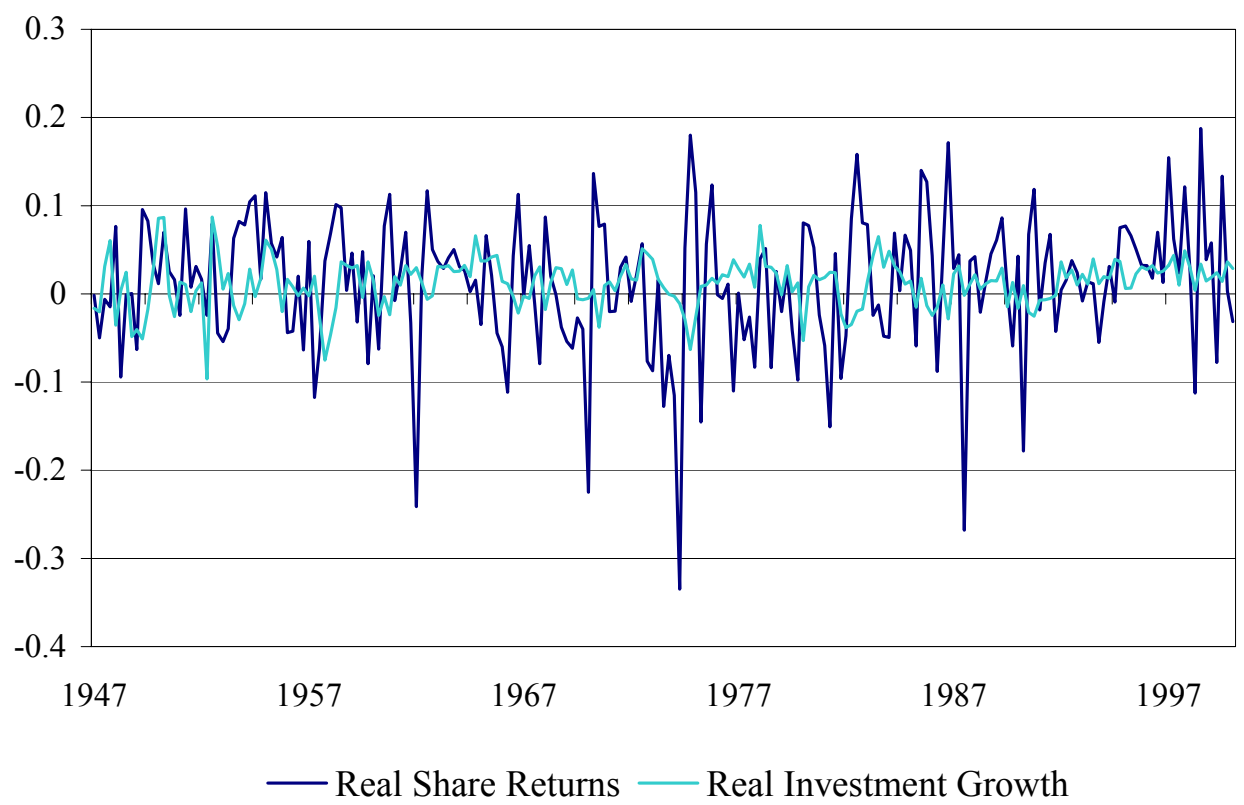


Figure 3. - Generalised IR of Investment to One SE Shock to Share Returns

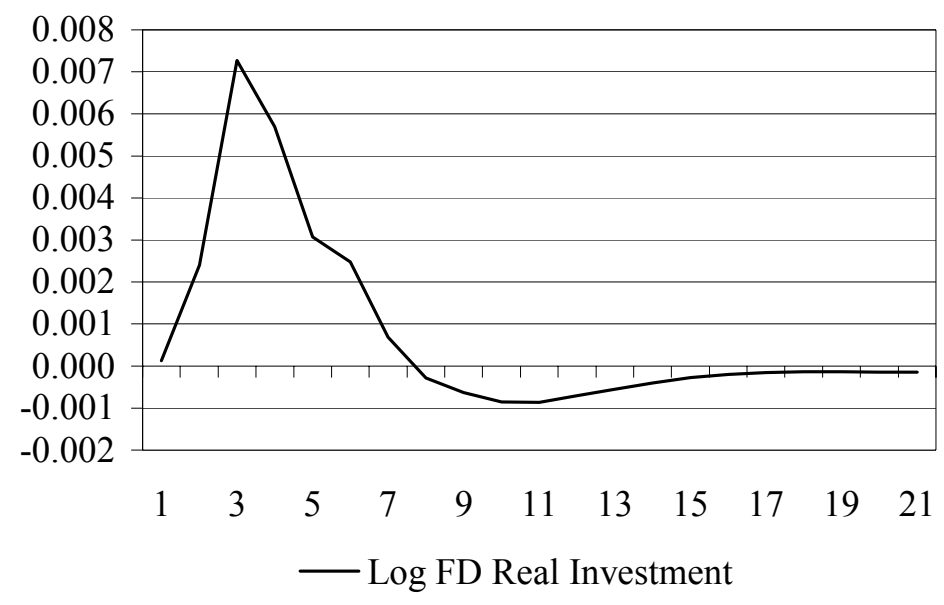

Figure 4.- Actual and Fundamental Share Prices: OLS Regression Decomposition

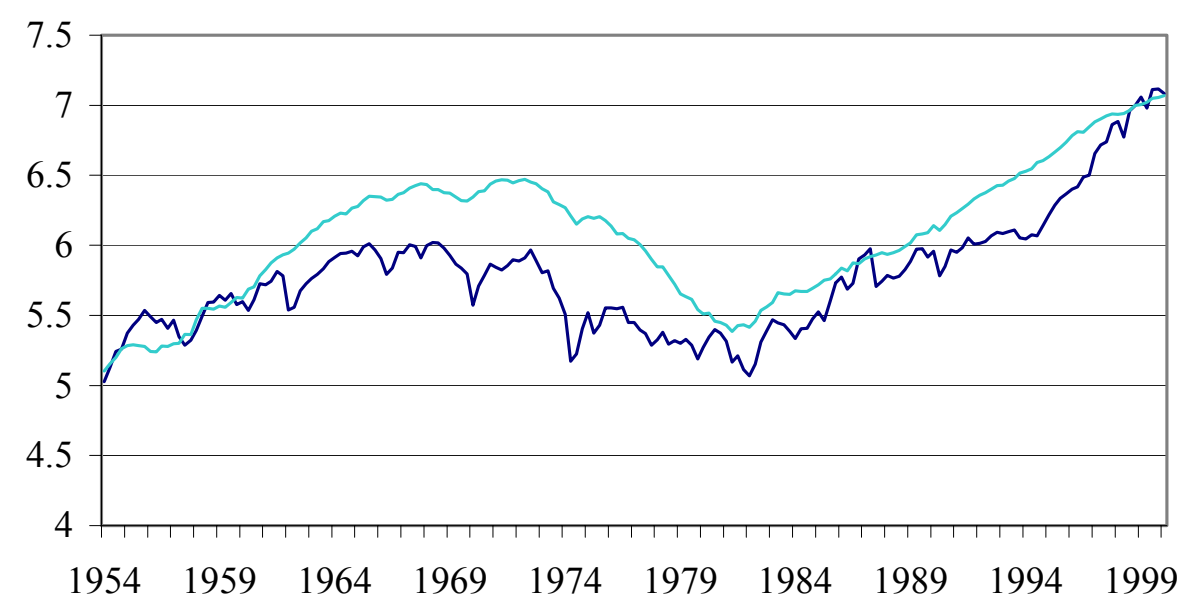

— Log Actual Share Price — Log Fundamental Share Prices 
Figure 5. Generalised IR of Investment to One SE Shock to Fundamental and Speculative Share Returns: OLS Regression Decomposition

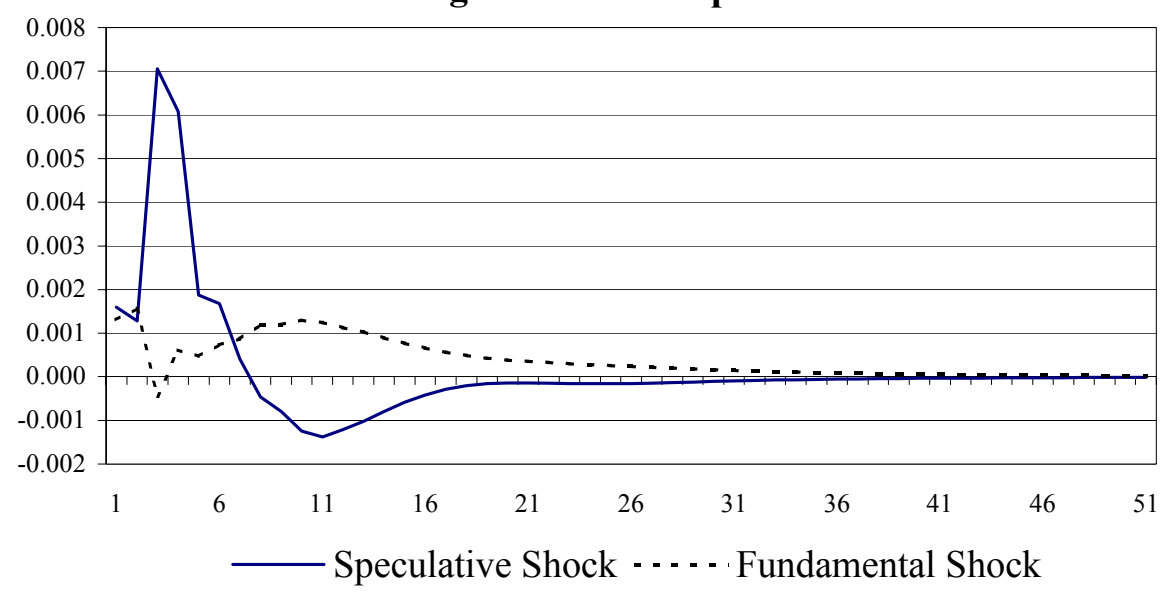

Figure 6. Long-Term Annual P/E ratio

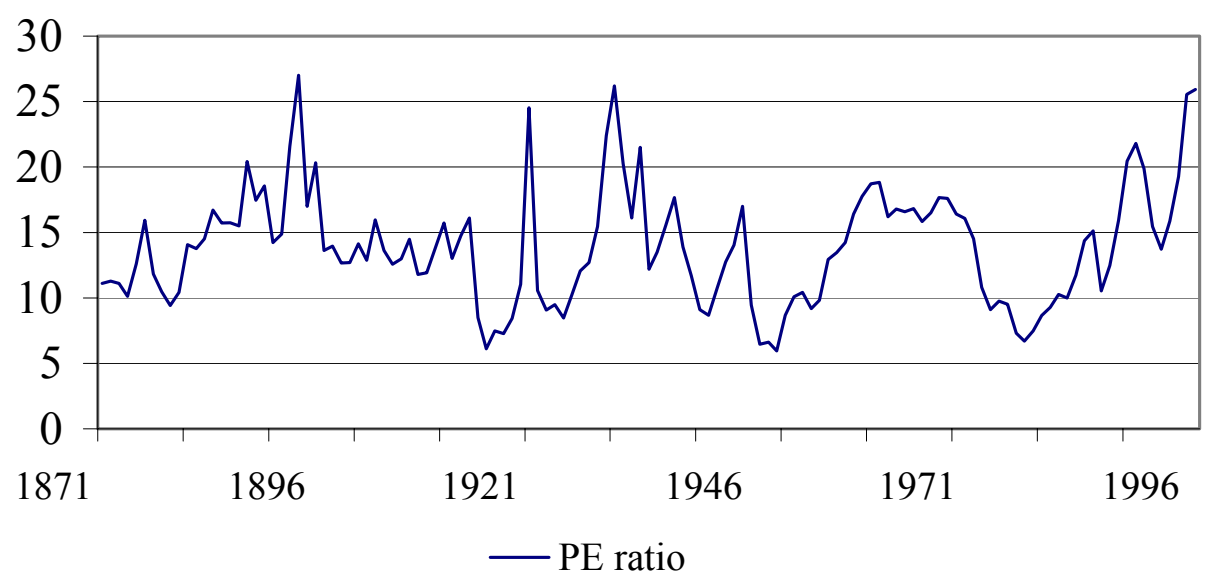


Figure 7. Actual and Fundamental Share Prices:

Long-Run P/E Based Decompositon

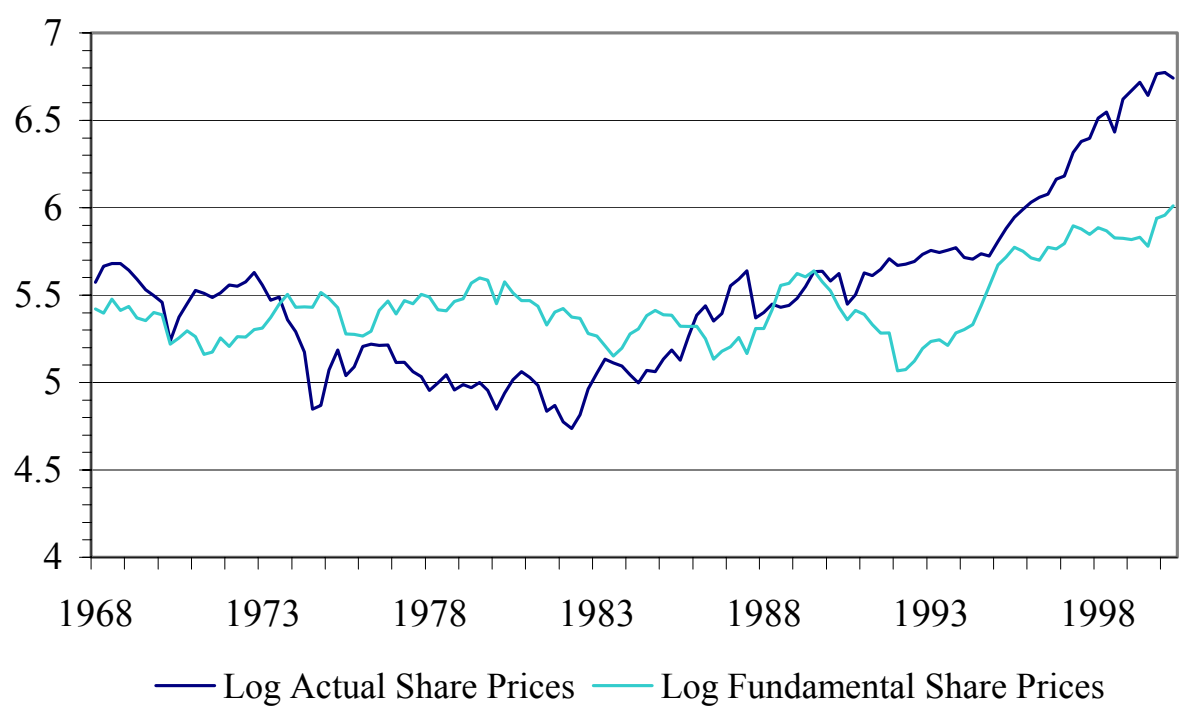

Figure 8. Generalised IR of Investment to One SE Shock to Fundamental and Speculative Share Returns: Long Run P/E

\section{Based Decomposition}

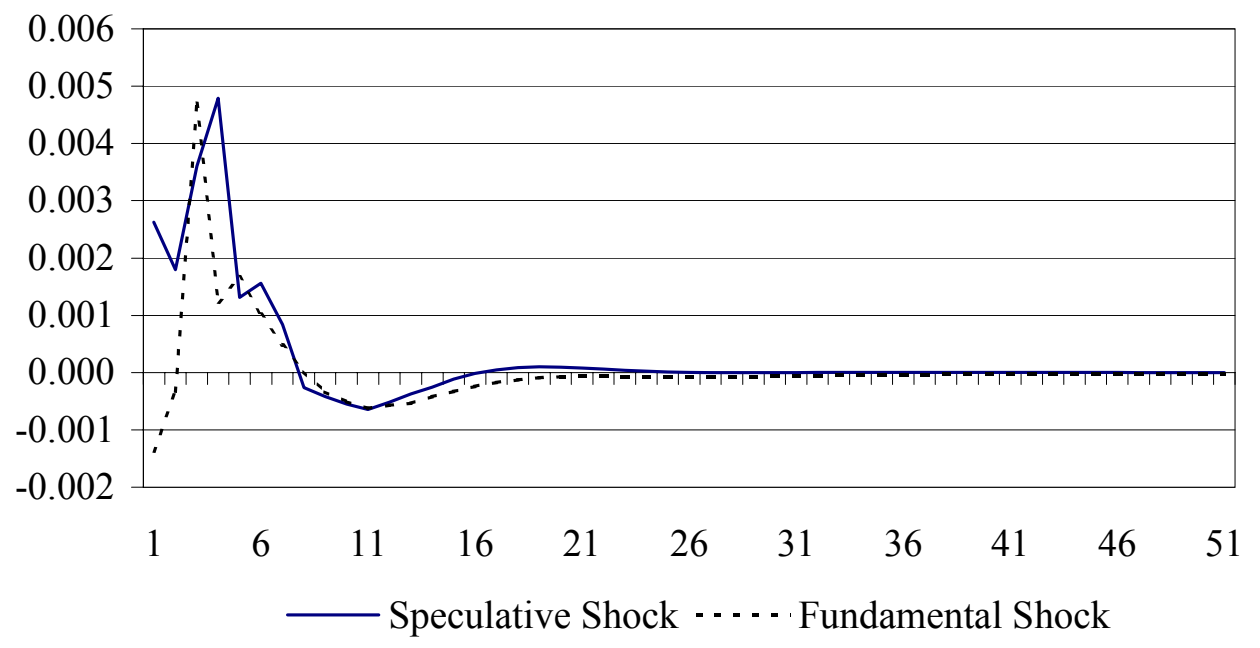


Figure 9. Actual and Fundamental Share Prices: Long-Run D/P Decomposition

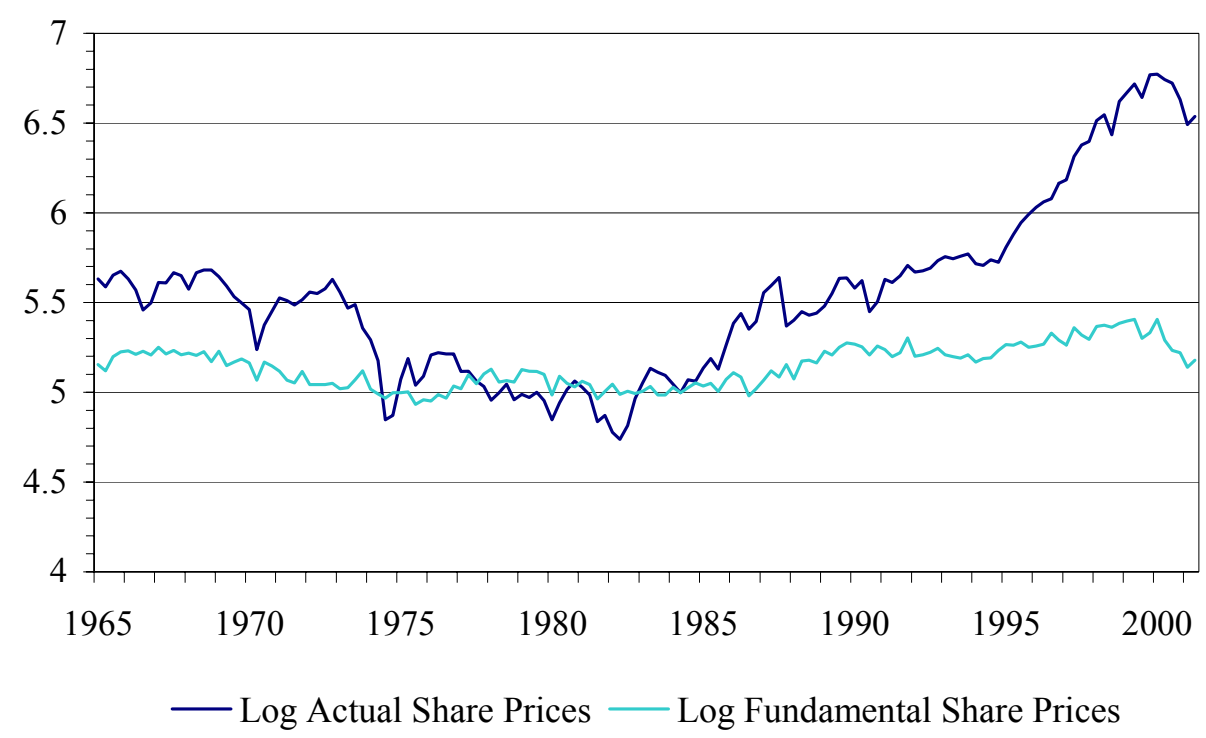

Figure 10. Generalised IR of Investment to One SE Shock to Fundamental and Speculative Share Returns: Long Run D/P Based Decomposition

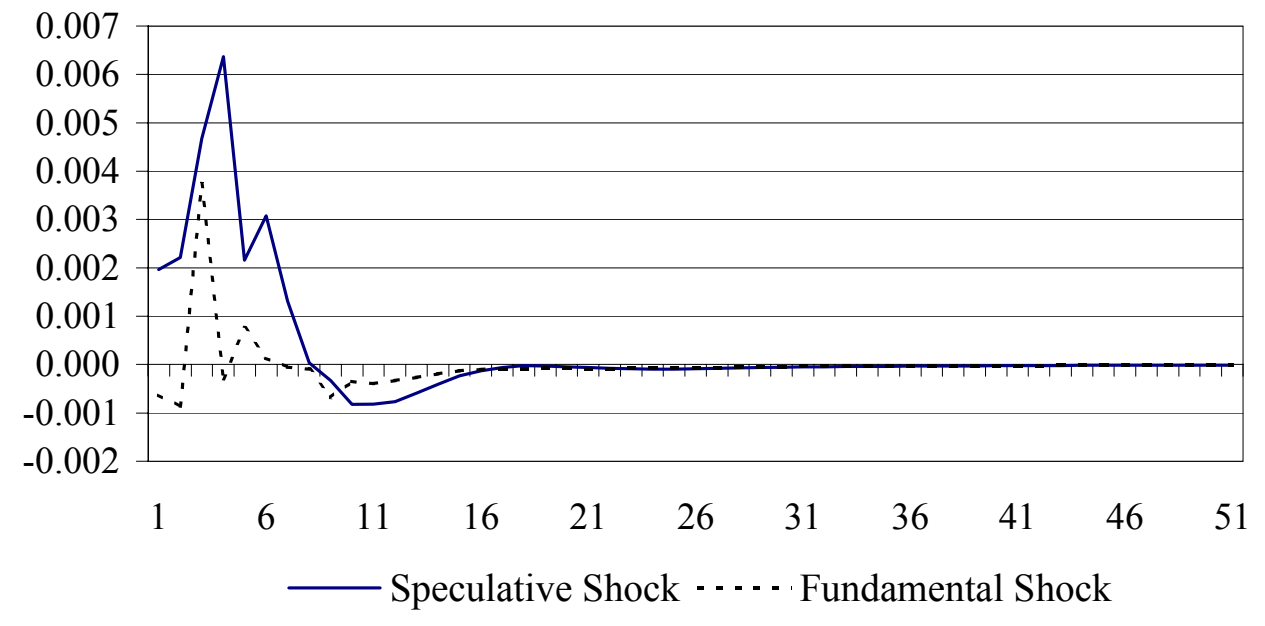


Figure 11. Actual and Fundamental Share Prices: Black et al. (2001) Decomposition

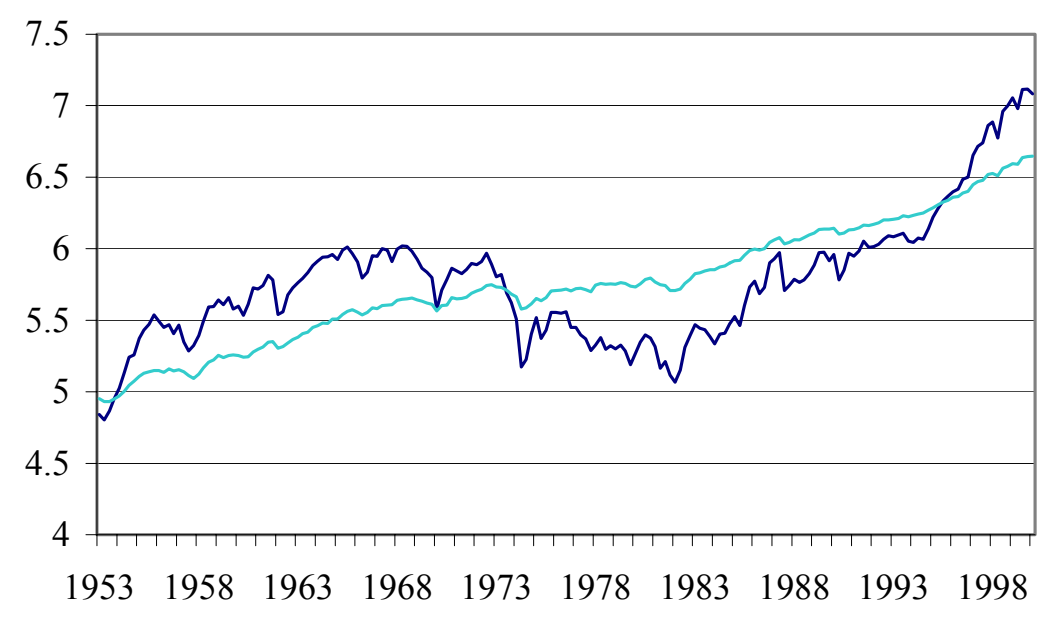

— Log Actual Share Prices — Log Fundamental Share Prices

Figure 12. Generalised IR of Investment to One SE Shock to Fundamental and Speculative Share Returns: Black et al. (2001) Decomposition

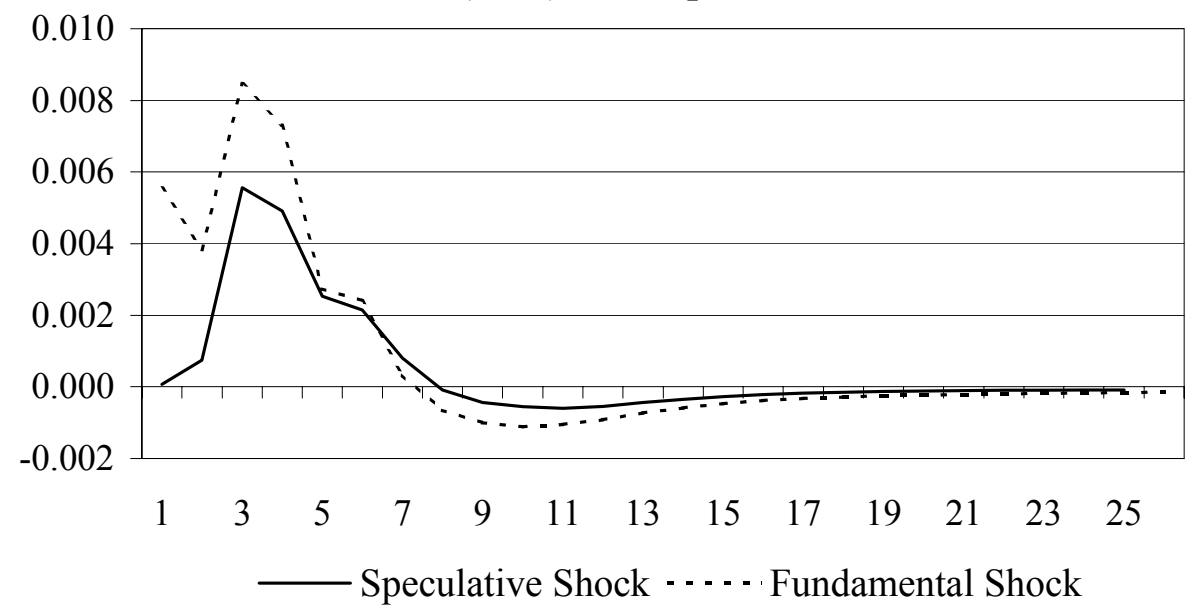

